Portland State University

PDXScholar

$5-19-1972$

\title{
Parental assessment of family life education content: analysis of one elementary school
}

William Richard Siefke

Portland State University

Follow this and additional works at: https://pdxscholar.library.pdx.edu/open_access_etds

Part of the Curriculum and Social Inquiry Commons, and the Social and Philosophical Foundations of Education Commons

Let us know how access to this document benefits you.

\section{Recommended Citation}

Siefke, William Richard, "Parental assessment of family life education content: analysis of one elementary school" (1972). Dissertations and Theses. Paper 1614.

https://doi.org/10.15760/etd.1613

This Thesis is brought to you for free and open access. It has been accepted for inclusion in Dissertations and Theses by an authorized administrator of PDXScholar. Please contact us if we can make this document more accessible: pdxscholar@pdx.edu. 
AN A BSTRACT OF THE THESIS OF Richard William Siefke for the Master of Social Work presented May 19, 1972.

Title: Parental Assessment of Family Life Education Content: Analysis of One Elementary School.

APPROVED BY MEMBERS OF THE THESIS COMMITTEE:

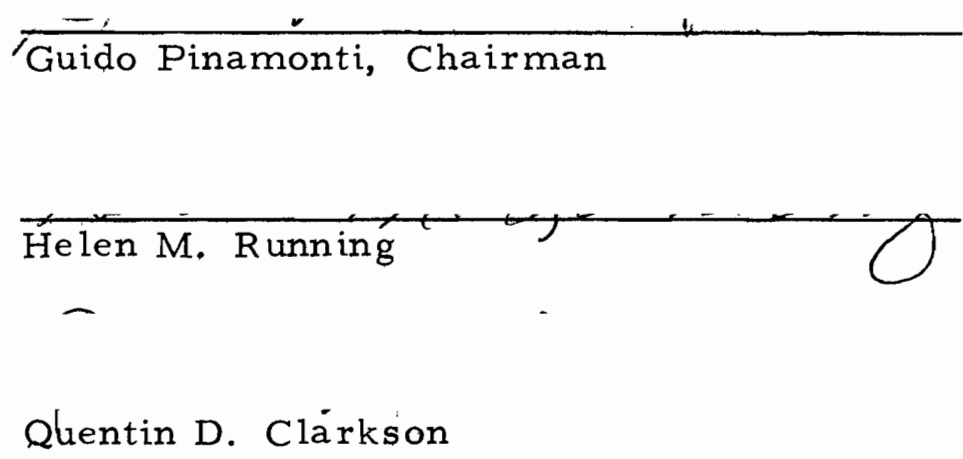

In this study the trends of social work were examined and the importance of the family in social work practice was identified. The changing role of the school and its relevance to the total welfare of the child was historically documented. The components of the family life education movement were analyzed as were the social forces which contributed to its growth and development. The incorporation of family life education into the schools was reviewed. The active involvement of several disciplines and numerous national organizations, as well as the federal government, was identified in this process.

The opposition to family life education being taught in the 
schools was identified as the problem to be examined in this study. The writer postulated that parents would be in favor of the school's teaching family life education if their knowledge concerning what was being taught was correct. Furthermore, it was hypothesized that if parents did not have correct information they would be more likely to disagree with the school's teaching family life education.

A randomly selected parent sample was drawn from an elementary school to test the hypothetical relationship between variables. A pre-test contributed to the development of a questionnaire that was better suited for use in this study. Nine representative family life education topics were included in a matrix format and five questions were asked to measure their knowledge and attitudes. Personal data concerning the age, occupation, ages of children, education, and church affiliation was supplied by the parents. A second instrument was designed to assess what was actually being taught by the teachers of the school. The same topics were used as on the parents' questionnaire.

The final response rate for the parents was $87.5 \%$ and for the teachers the return was $65.3 \%$. Limitations in the data collected prevented the verification of the hypothesized relationship between the variables. However, the parents of this study reflected higher levels of education than anticipated as $60 \%$ had completed various levels of college. Their occupations indicated a higher amount of 
professional and white collar workers than blue collar workers.

These parents supported the school's teaching of the family life topics by a definite majority. However, opposition was expressed by $17 \%$ of the sample to "human sexuality" being taught. Another $14 \%$ opposed teaching "about one's family." A significant finding of this study was the widespread uncertainty by the parents concerning what was being taught. For seven of the nine topics $40 \%$ to $60 \%$ of the sample was uncertain if it was being taught. Concern for the training and beliefs of those teaching the topics was expressed by $20 \%$ of the sample.

Further study in the area of the causes of the parental ambivalence concerning the teaching of family life education and the need to compare this study's findings and the personal profile of the se parents to other schools was indicated. The paradox between the parents' support of the school teaching family life education and the uncertainty as to what was actually being taught suggests a need for further study into the causes of this phenomena. 
PARENTAL ASSESSMENT OF FAMILY LIFE EDUCATION CONTENT: ANALYSIS OF.

ONE ELEMENTARY SCHOOL

$$
\text { by }
$$

RICHARD WILLIAM SIEFKE

\author{
A thesis submitted in partial fulfillment \\ of the requirements for the degree \\ of \\ MASTER OF SOCIAL WORK \\ Portland State University \\ 1972
}


TO THE OFFICE OF GRADUATE STUDIES:

The members of the Committee approve the thesis of Richard William Siefke presented Mav 19. 1972.

Ghido Pinamonti, Chairman

a)

Helen M. Running

Quentin D. Clarkson

APPROVED:

Gordon Helalrn. Dean. School of Social Work

Dafid T. Clark, Dean of Graduate Studies

May 19, 1972 


\section{ACKNOW LEDGMENTS}

The writer would like to express his appreciation and heartfelt thanks to all those persons who have assisted him in this study during the past year. For the constant support and unwavering understanding of his wife, Deanna, the writer is especially grateful. The thoughtfulness and interest of the writer's stepson, Bradley, has been a big contribution and deserves special thanks.

The sacrifices of the writer's family have been matched by those of his thesis committee chairman, Dr. Guido Pinamonti. $\mathrm{He}$ has given of himself and his time both freely and willingly. His encouragement and support have been as useful as were his questioning and inquiry into problem areas. The writer greatly appreciates the approach of Dr. Pinamonti to his role as he let this thesis evolve from the writer's perspective. However, his guidance in this process was not haphazard and he helped the writer to confront the salient issues in this study. Dr. Pinamonti has demonstrated in this process his high professional standards and the writer is indebted to him for his assistance while serving as his thesis committee chairman.

As the writer's outside committee member, Mrs. Helen Running focused on the realities of this study from her experience as a family life educator. Even though she was very busy with school and family activities the writer appreciates the fact that she was 
always available for consultation. The writer is grateful to Mrs. Running for her assistance throughout this study.

Dr. Dean Clarkson gave needed technical guidance in the formation of the research instruments and in improving the design for this study. The writer gratefully acknowledges the aid he received from him in the analysis of data. The writer appreciates the suggestions of one of Dr. Clarkson's research classes which aided the writer in the construction of the parental assessment questionnaire. The help and interest of the principal of Jason Lee School, Mr. Custis Green, is acknowledged. Mr. Green worked with the writer in matters pertaining to the parents and teachers as well as the data collection and his contributions are appreciated. The writer's most frequent contact with the school was with Mrs. Bonnie Thomas, Mr. Green's secretary. Although very busy with school matters, Mrs. Thomas was always willing to assist the writer in whatever fashion needed, and her help is appreciated.

The writer was aided by the clerical skills of his typists during various phases of this study. Among them are: his wife, Deanna, Mrs. Vicki Mackey and Mrs. Joy Behrends. Special thanks are due Mrs. Ilene Anderton and Mrs. Clover Redfern who prepared the final draft which was multilithed by Type-Ink of Corvallis, Oregon.

However, this study would not have been possible without the cooperation of the parents and teachers of Jason Lee School.who we re willing to participate. Their contributions were enlightening and helpful. 


\section{TA BLE OF CON TENTS}

PAGE

ACKNOW LEDGMENTS

LIST OF TABLES

vii

\section{CHAPTER}

I INTRODUCTION $\ldots \ldots \ldots \ldots$

Trends in Social Work . . . . . . . . 5

Changes Toward Progressive Education . . 11

Reasons for the Study ............ 14

Statement of the Problem ......... 15

Purpose of the Study . . . . . . . . . . 18

Definition of Family Life Education . . . . 19

The Importance of Family Life Education . 22

II THE FAMILY LIFE EDUCATION MOVEMENT • • 26

Beginnings . . . . . . . . . . 29

Components . . . . . . . . . . . 31

Summary ............. . 54

III METHODOLOGY . . . . . . . . . . 57

Selection and Construction of Instruments . 59

Data Collection ............ 67

The Nature of the Report . . . . . . 72 
IV FINDINGS . . . . . . . . . . . . . 74

Identifying Characteristics of the Sample . . 74

Data Analysis .......... . 79

Results ............... 80

Limitations of the Study . . . . . . 88

Interpretations . . . . . . . . . . 90

$\mathrm{V} \quad \mathrm{IMPLICATIONS}$. . . . . . . . . . . . 94

BIBLIOGRA PHY . . . . . . . . . . . . . . . . 98

APPENDICES . . . . . . . . . . . . . . . 107 


\section{LIST OF TABLES}

Table

Page

I. Persons Completing Parental Assessment

Questionnaire ................. . . 70

II. Teachers Completing Teacher Survey . . . . . . 72

III. Family Size and Frequency of Opposition to the Family Life Education Topics . . . . . . . . . 76

IV. Educational Achievement of Parents . . . . . . . 77

V. Parental Responses to Question One (PAQ) . . . . 81

VI. Percentage of "Uncertain" Responses to Question Two (PAQ) . . . . . . . . . . . . . . . . 85

VII. Parents Opposed to the Teaching of Certain Family Life Education Topics Who Were "Uncertain" if Topic Was Being Taught . . . . . . 86 


\section{CHAPTER I}

\section{INTRODUCTION}

A preliminary report prepared for the 1970 White House Conference on Children stated that, ". . the family in the United States is in trouble. " 1

Similar statements and recommendations concerning the needs and status of the family have been made at other conferences throughout the twentieth century. When viewed within a historical framework it would appear that these reports urge revolutionary change. However, the family has always been changing and since Biblical times it has proceeded through many transitions.

The study of the family and the changes it has undergone is certainly not a new field. In his review of the growth of this academic endeavor, Christensen traces its evolution through three periods or stages. The first of these is the theological or pre-research stage. Second is the metaphysical or philosophical. And third, he cites the positivistic or scientific. The first period ended around 1860. The

${ }^{1}$ Barbara A. Chandler, "The White House Conference on Children: A 1970 Happening, " The Family Coordinator, XX, No. 3 (1971), p. 195 . 
second continued until the end of the nineteenth century. And the final stage began with the turn of the century and is descriptive of the field at the present. 2

As mentioned above, the family and its importance has been the subject of much attention throughout history. In support of the family's importance, Goode submits that without a set of social forces that respond to the individual to support his internal controls, as well as the controls of the formal agencies or authorities of society, the society will not survive. He feels that the family provides this set of forces that serves both the individual and society. 3

That the family has and is experiencing change is a given, yet there are two basic and irreducible functions that Parsons suggests will not change. These are: "1) the primary socialization of children so that they can truly become members of the society into which they have been born; and 2) the stabilization of the adult personalities of the population of the society. $" 14$

${ }^{2}$ Harold T. Christensen, "Development of the Family Field of Study, " in his (ed.) Handbook of Marriage and the Family (Chicago: Rand McNally and Company, 1964), p. 10.

${ }^{3}$ William J. Goode, The Family (Englewood Cliffs, New Jersey: Prentice-Hall, Inc., 1964), p. 2.

${ }^{4}$ Talcott Parsons, Robert F. Bales, and James Olds, Family Socialization and Interaction Process (Glencoe, Illinois: The Free Press, 1955), pp. 16-17. 
The universality of the nuclear family has been clearly estab-

lished by Murdock in his study of 250 representative human societies.

He found that:

In the nuclear family or its constituent relationships, we thus see assembled four functions fundamental to human life--the sexual, the economic, the reproductive, and the educational. Without provision for the first and third, society would become extinct; for the second, life itself would cease; for the fourth, culture would come to an end. The immense social utility of the nuclear family and the basic reason for its universality thus begin to emerge in strong relief. 5

Murdock's findings reveal that other agencies or relationships may share in the fulfillment of these functions, but will not replace the family.

The nature of the family's present condition has been the subject of much attention in the literature. ${ }^{6}$ Although arguments have been proposed on both sides of this issue, the majority would probably agree that the family is in need of assistance.

In his analysis of the overwhelming changes that affect the individual in today's world, Toffler feels that the family may neither

${ }^{5}$ George Peter Murdock, "The Universality of the Nuclear Family, " in A Modern Introduction to the Family, ed. by Norman W. Bell and Ezra F. Vogel (revised ed.; New York: The Free Press, 1968), p. 43.

${ }^{6}$ For example, see David Cooper, The Death of the Family (New York: Pantheon Books, 1970); John N. Edwards, ed., The Family and Change (New York: Alfred A. Knopf, Inc., 1969); or Herbert A. Otto, ed., The Family in Search of a Future (New York: Appleton-CenturyCrofts, 1970). 
vanish nor move into a Golden Age. ${ }^{7}$ Instead, he believes that it may dissolve only to return in novel and weird variations. As a strategy for survival in the coming, if not present, era of "super-industrialism" he suggests that educational curriculums be organized around the human life cycle: birth, childhood, adolescence, marriage, career, retirement, and death; or around contemporary social problems instead of such basics as English, economics, mathematics, and biology (Toffler, p. 410).

In response to our rapidly changing society and the effects that it has on the individual and his family, it is essential that society's members can adapt to the fast pace and swift changes. As a result of the increased needs of and demands on the person to cope, if not survive in a changing world, individuals have joined together to develope new mechanisms that would allow them to live in dynamic harmony with their society. One such innovation is family life education. From its early tentative beginnings, it has grown to become a part of many a school's curriculum. The proposed curriculum changes advanced by Toffler would be a deepening and expanding of what family life education has been in the schools for decades.

The skills that Toffler views as necessary for the individual to successfully cope with the future are synonymous with what Frank

${ }^{7}$ Alvin Toffler, Future Shock (New York: Random House, Inc., 1970), p. 239. 
views as the challenge of family life education. Frank writes that, "The concept of an everchanging family configuration is central to family life education, "and defines this as a sequential process of transformation in which each individual family member ". . revises, enlarges, and gives up old to replace with new patterns of behavior, relations, and feelings. ${ }^{8}$ In this respect, social work stands in the mainstream of those professions whose dominant concern has been the family and its members in their struggle to keep pace with the chang:ing milieu.

\section{TRENDS IN SOCIAL WORK}

Modern social work and social welfare programs developed out of the concern for the "dependent" individual of the mid-nineteenth century. Segments of American society have organized to deal with certain problems faced by its members prior to this time. 9 However, the rise of social work as a profession and the growth of the welfare state in America did not begin until the period around the middle of the

${ }^{8}$ Lawrence K. Frank, "Challenge of Family Life Education," Merrill Palmer Quarterly of Behavior and Development, V, No. 2 (1959), p. 73.

${ }^{9}$ For an analysis of such efforts, see Elizabeth A. Ferguson, ed. , Social Work (2nd ed.; Philadelphia: J. B. Lippincott, 1969), p. 60; and Harry L. Lurie, "The Development of Social Welfare Programs, " in Social Work Year Book 1960, ed. by Russell H. Kurtz (New York: National Association of Social Workers, 1960), pp. 19-49. 
nineteenth century when state boards of charities and correction were organized. Massachusetts formed the first such board in 1863 with New York and Ohio following suit in 1867 ; by 1897,16 states had formed such boards (Lurie, p. 28).

Another development which contained the seeds of social work's concern for the family was the Charity Organization Society movement. The first American Charity Organization Society was founded in 1877 in Buffalo, New York. This movement had its beginnings in England with the founding of the London Charity Organization Society in 1869. By 1887, there were 25 cities in America which had formed similar societies (Lurie, p. 29). These organizations were formed to find ways and means of helping poor families through individualized services (Ferguson, p. 63). Interestingly, this period was characterized by a tremendous population growth, and America's population grew 141 percent during the years $1860-1900 .^{10}$

Immigration was a main contributor to this growth and another movement grew out of the problems connected with this new population (Cohen, p. 75). The settlement house movement which also had its origin in England, began in America in 1886 when the Neighborhood Guild was established in New York City. Hull House in Chicago was organized in 1889. Other settlements were founded and by 1929, there

${ }^{10}$ Nathan Edward Cohen, Social Work in the American Tradition (New York: The Dryden Press, Publishers, 1958), p. 75. 
were 160 settlement houses which had membership in the National Federation of Settlements (Lurie, p. 30).

This movement began as a result of the problems faced by the immigrant in a new culture. Its early emphasis was on Americanization (Ferguson, p. 67). Later unemployment and the problems of the slums captured its attention. In their efforts to assist the people in the neighborhood, the early settlement workers were forced to consider the influences on the individual from the general social and economic setting of the city, state and nation (Lurie, p. 30).

This change of concentration culminated in a social reform movement which focused on the conditions in which the individual lived. The attention given individual defects was shifted from internal forces (causes) to external or environmental conditions and, "The study of all the factors in the family situation laid the groundword for the modern concept of study, diagnosis, and treatment" (Cohen, p. 113). In summary, the emphasis was changing and "Relief was becoming more than an end in itself and was a tool for building the responsible selfmaintenance family unit" (Cohen, p. 113).

Hence, the early trend in social work of individual philanthropy and improving conditions of the poor changed to a more sociological perspective as social work looked beyond the individual to his environment and to the broader social aspects of this problem (Cohen, p. 70). The Charity Organization Society movement and the 
settlement house movement are related to each of these trends. The social reform movement which began around the turn of the century was the outgrowth of this increased awareness by social workers of the influences which social forces had on the individual.

The early social worker who visited the family during the Charity Organization Society movement was interested in getting to know the family so as to individualize his service to their specific needs. ${ }^{11}$ This movement helped to establish family service agencies and family casework (Ferguson, p. 65). As the worker became more aware of the problems experienced by the family and its members, the social reform movement grew and it worked toward improving labor conditions and laws concerning children, women, and the working man, better housing regulations to improve the slums, increase health standards (Ferguson, p. 60), and social justice. ${ }^{12}$ The expanding emphasis on family life was brought into national view in 1909 by the White House Conference on the Care of Dependent Children. This conference made explicit the importance of the family and the home to the welfare of children (Lurie, p. 33).

${ }^{11}$ Frank J. Bruno, Trends in Social Work 1874-1956 (2nd ed.; New York: Columbia University Press, 1957), p. 184.

12 Robert Bremner, "A Note on the Role of Social Workers in the Reform Movement, "in Perspectives on Social Welfare, ed. by Paul E. Weinberger (London: The Macmillan Company - Collier Macmillan Limited, 1969), p. 88. 
Out of the Charity Organization Society movement also came the advancement of social work toward professional status. With the establishment of training programs for social workers by the New York Charity Organization Society the foundation for the first professional school of social work was laid. In 1904, the New York School of Philanthropy, now the Columbia University School of Social Work, was established. 13

From the foregoing it is obvious that throughout its development, social work has been concerned with the individual and his family. The family became even more important to social work as it incorporated Freudian theory into its theoretical framework. The family has been so prominent in social work practice that Wilensky and Lebeaux write that, "Family service is highly identified with social work. "14

Another significant aspect of social work practice began during the social reform era. In the academic year of 1906-1907, social workers became directly involved with several schools. Simultaneously during this year in Boston, New York, and Hartford, school social work has its beginning. ${ }^{15}$ These developments were the direct

13 Arthur E. Fink, C. Wilson Anderson and Merrill B. Conover, The Field of Social Work (5th ed.; New York: Holt, Rinehart, and Winston, Inc., 1968), p. 71.

${ }^{14}$ Harold Wilensky and Charles Lebeaux, Industrial Society and Social Welfare (New York: Russell Sage Foundation, 1958), p. 298.

${ }^{15}$ Lela B. Costin, "A Historical Review of School Social Work," Social Casework, XLIX, No. 10 (1969), pp. 439-440. 
result of: 1) the passage of compulsory school attendance laws;

2) new knowledge about individual differences among children and their capacity to respond to improved conditions; and 3) the realization of the strategic place of the school and education in the lives of children and youth, coupled with a concern for the relevance of education to the child's present and his future. A logical outgrowth was that: (1) social workers were increasingly involved in helping the school meet its responsibility for the total welfare of the child; and (2) in working toward securing maximum cooperation between school and home (Costin, p. 440). Through their involvement in the schools, social workers contributed to the understanding of how forces outside of the school affected the child's ability to make use of the learning opportunities provided by the school. The importance of the school was clearly stated by Sophonisba P. Breckinridge in an address to the National Education Association in 1914. She said:

To the social worker the school appears as an instrument of almost unlimited possibilities, not only for passing on to the next generation the culture and wisdom of the past, but for testing present social relationships and for securing improvements in social conditions (Costin, p. 441).

This stance concerning the school's function and responsibility and the contribution of school social work parallel, in part, the goals of family life education. ${ }^{16}$ In fact, these early bonds between the school

${ }^{16}$ The goals of family life education will be examined in the Definition of Family Life Education section of the present chapter. 
and the social work profession can be viewed as a part of the progressive education movement which contributed to family life curricula being incorporated into the educational system.

\section{CHANGES TOWARD PROGRESSIVE EDUCATION}

When the Pilgrims in Massachusetts were required by the Old Deluder Satan Act of 1647 to establish schools, America's educational beginnings reflected European patterns. ${ }^{17}$ During the 325 years since the founding of America's first school, the philosophies of Locke, Rousseau, Herbart, Pestalozzi, Comenius, and others have beget change in our educational system. ${ }^{18}$ Education in America has not always been free nor public and it was not until after the Civil War that the rudiments of our free public school system were formed (Pullian, p. 67). Horace Mann, James G. Carter, and Henry Barnard were largely responsible for the founding of our present day public school system (Pulliam, p. 43).

The most dramatic of changes in our educational system came around the turn of the century. The Industrial Revolution and the

17 John D. Pulliam, History of Education in America (Columbus, Ohio: Charles E. Merrill Publishing Company, 1968), p. 11.

18

For an historical analysis of American education and the philosophical influences affecting it, see Ernest E. Bayles and Bruce L. Hood, Growth of American Educational Thought and Practice (New York: The Macmillan Company, 1966), and H. G. Good, A History of American Education (2nd ed.; New York: The Macmillan Company, 1962). 
changes accompanying it made new demands on the schools. ${ }^{19}$ During the period of 1890-1918, social reformers were critical of American society and worked for reform in many areas. Among these was the educational system. Education was criticized as being too intellecualistic. A curriculum that would be more practical and useful was advocated by those seeking change. 20 This suggested change in the curriculum was based on far different conceptions of the school, its relationship to society, and to those attending school than the orientations present at that time (Cremin, p. 141).

Evolving at that time was a growing body of knowledge concerning child development. This began with the work of G. Stanley Hall, who in 1891 published The Contents of Children's Minds on Entering School. Other insights based on learning theory came from the endeavors of Edward L. Thorndike and had an influence on the reform movement (Cremin, p. 143, 144).

Those urging reform in education felt that the school should work for the welfare of society by transmitting ideals and attitudes

${ }^{19}$ Lawrence A. Cremin, "The Revolution in American Secondary Education, 1893-1918; "iff Éñtemporafy Aherican Education, ed. by Stan Dropkin, Harold Full and Ernest Schwarcz (2nd ed.; New York: The Macmillan Company, 1970), p. 141 .

${ }^{20}$ R. Freeman Butts, "Search for Freedom: The Story of American Education, " in Contemporary American Education, ed. by Stan Dropkin, Harold Full and Ernest Schwarcz (2nd ed.; New York: The Macmillan Company, 1970), p. 108. 
toward life to its constituency. ${ }^{21}$ Responding to the se criticisms, the school gradually became an institution not only focused on the intellectual development of children but also one increasingly concerned with their socialization.

Foremost among those striving for this kind of change was John Dewey. As a psychologist, philosopher, and educator, his educational experiments and writings received much attention and contributed to the new role of education in America. Dewey stressed the relation of the school to the culture in The School and Society which was published in 1899. The nature of his philosophy can be seen in the following excerpt from Democracy and Education, published in 1916 . He wrote:

A society which makes provisions for participation in its good of all its members on equal terms and which secures flexible readjustments of all its institutions through interaction of the different forms of associated life is insofar democratic. Such a society must have a type of education which gives individuals a personal interest in social relationships and control, and that habits of mind which secure social changes without introducing disorder. 22

The philosophy of Dewey was embodied in the progressive education movement. The following beliefs were basic to its philosophy:

${ }^{21}$ Charles L. Robbins, The School as a Social Institution (Boston: Allyn and Bacon, 1918), pp. 34, 37.

${ }^{22}$ John Dewey, Democracy and Education (New York: The Macmillan Company, 1916), p. 115. 
1) Man is an organism which acts as a whole.

2) Education is the continuous and steady effort to act intelligently with the situation by the use of past experience.

3) The concept of a rapidly changing world.

4) That man can share to a greater degree in the determination of his destiny. 23

The Progressive Education Association, founded in 1918, worked effectively to implement these philosophical tenants and bring about changes in the schools (Folsom, p. 68).

This change in our educational system marked the schools demonstrative concern for the total lives of individuals. Without such a change, family life education could not have been woven into the fabric of American education.

\section{REASONS FOR THE STUDY}

Like Toffler, Frank and others, the writer agrees that it is necessary for schools to assist the individual and the family. A survey of why family life educators chose their field has revealed several common reasons. Among them were "to help people" and "an interest

${ }^{23}$ Joseph K. Folsom, Youth, Family and Education (Washington, D. C. : American Council on Education, 1941), p. 68. 
in the family as a result of their own happy family background. "24

The writer's choice of profession was based upon reasons similar to those cited in the survey above. The desire to help others and an interest in the family (based on a happy family background) has also focused the writer's attention on family life education as a preventive treatment modality. Since the goal of social work, as stated by Boehm, is ". . . the enhancement of one's social functioning. . " 25 there are numerous vehicles which social work as a profession can or might use to attain this desired result. When so many of the personal problems an individual encounters affect the family, it is apparent why professionals of many disciplines believe family life education to be an expedient intervention. Therefore, the writer perceives this study to be a germane endeavor, consistent with the goals of the social work profession.

\section{STATEMENT OF THE PROBLEM}

Family life education in the schools has always been a controversial is sue and more so at some times than at others. For example, during the 1960's the intense polemic response concerning this aspect

24 Glen A. Christensen, "An Analysis of Selected Issues in Family Life Education, " (unpublished master's thesis, Michigan State University, 1958), p. 99.

${ }^{25}$ Werner W. Boehm, "The Nature of Social Work, "Social Work, III, No. 2 (1958), p. 10. 
of the school's curriculum gathered enough momentum that it has carried on into the $1970^{\prime} \mathrm{s}^{26}$

The year 1969 was characterized by strong opposition ${ }^{27}$ to one element of family life education; namely, sex education. The organizations and personalities behind the campaign to ban sex education from the schools were identified in a survey conducted by The Family Coordinator's Family Life Education Reaction Panel. ${ }^{28}$ The panel was composed of 43 teachers, administrators, authors, and national leaders in the family life field. In its survey it found that the John Birch Society and its Movement to Restore Decency Committee (MOTOREDE), the Christian Crusade, the Dan Smoot Report, and other groups of people who were identified as "reactionaries," "fundamentalists," "conservatives" and "The Far Right" were responsible for concerted opposition to the teaching of sex education in the schools (Kerckhoff and panel, p. 105).

${ }^{26}$ Janet S. Brown, "Improving Family Life: Action and Reaction," Journal of Marriage and the Family, XXXII, No. 4 (1970), p. 598.

${ }^{27}$ The reader is referred to Appendix $E$ for a partial listing of national organizations who have gone on record in support of sex education being taught in the public schools.

${ }^{28}$ Richard K. Kerckhoff and The Family Coordinator Family Life Education Reaction Panel, "Community Experiences with the 1969 Attack on Sex Education, "The Family Coordinator, XIX, No. 1 (1970), p. 105. 
The writings of Gordon Drake of the Christian Crusade incorporate misquoted and distorted information which is used in such a way as to suggest or imply that teaching sex education would ". . . seduce the minds and morals of little children. "29 Similar efforts of the John Birch Society also reflect distortion and falsehood in their published statements on this issue. The following is the statement of the Executive Committee of the Society as it announced its new requirement for the MOTOREDE committees:

That requirement is organized, nationwide, intensive, angry and determined opposition to the now mushrooming program of so-called sex education in the public schools. Various stages of the program have already been imposed on some five to ten percent of the schools. Deep laid plans have been carefully initiated to spread this subversive monstrosity over the whole American educational system from kindergarten to high school. But a preponderent majority of the American people are not yet even aware of this filthy Communist plot, of the tremendous drive that is behind it, or of its triple significance.

(The program) begins, for instance, with varied and elaborately designed exhibits, colored slides, and other visual aids, to demonstrate the raw facts of sex to children from three to eight years old!. . . Increasingly, in classes for older boys and girls, the instruction on sexual methods is followed by encouragement to experiment and practice.. .

In schools where the full program has been adopted--and all of the usual Communist-style falsehoods, deceptions, pressures, and pretenses are subtly utilized to get school boards to fall in line--it is not unusual for a high school teacher to ask his students (boys and girls together, ages fifteen to eighteen) to tell the class about, or write themes about, their participation in the

${ }^{29}$ Luther G. Baker, Jr., "The Rising Furor over Sex Education," The Family Coordinator, XVIII, No. 3 (1969), p. 210. 
following activities: kissing, masturbation, light petting, fondling breasts, or genitals (for boys), fondling male genitals (for girls), sexual intercourse, sexual activities to near intercourse, and sexual activities with an animal (Baker, pp. 214-215).

Although sex education is viewed as an important element of family life by the National Council on Family Relations, it is not perceived as the essence of family life education. ${ }^{30}$ Nonetheless, the former is often times thought to be synonymous with family life education by the public. Many of the public believe that family life education is just another name for sex education. Therefore, the attacks on sex education can also be perceived as attacks on family life education. The problem that this study investigated was the quality of information possessed by the parents concerning family life education in the schools and their emotionality related to it.

\section{PURPOSE OF THE STUDY}

The purpose of this study was to measure the validity of the information held by the parents of elementary school children and assess how their information concerning the family life education curriculum as taught by the school affected their opinions concerning the school's teaching such curricula. The writer was interested in answering the following questions:

${ }^{30}$ National Council on Family Relations, 'Position Paper on Family Life Education, "The Family Coordinator, XIX, No. 2 (1970), p. 186. 
1) Is there a relationship between what a parent thinks about family life education as taught by the school and what the parent believes is being taught in family life education by the school?

2) Do parents who support the teaching of family life education in the school have correct information concerning what is being taught in its family life curriculum?

3) Do parents who oppose the teaching of such curricula have incorrect information concerning its content?

Before these questions can be answered it is necessary to define the meaning of family life education.

\section{DEFINITION OF FAMILY LIFE EDUCATION}

Family life education is viewed differently by various people in the field. As a result, there has not been an agreement on a single definition. A study conducted by Avery in 1963 surveyed 90 experts in three segments of the family life education field in an attempt to gain closure on a definition of family life education conducted in the schools. ${ }^{31}$ The respondents were from college and university faculties, community and national agencies, and teachers and

${ }^{31}$ Curtis E. Avery and Margie R. Lee, "Family Life Education: Its Philosophy and Purpose, "The Family Life Coordinator, XIII, No. 2 (1964), p. 27. 
administrators of the public schools. A working definition was formulated and the experts were asked to respond to that definition. The results showed that some of the experts thought it was too borad, others felt that it was too limiting, and some agreed with it; thus pointing out the problems in coming to a universal definition. What follows is a synthesis of what was learned from the Avery survey.

1) The ultimate goal of family life education is the development of stable families contributing constructively to the society in which they live.

2) Family life education is a continuing process throughout the lifetimes of the individuals with whom it deals.

3) Family life education in any of its various settings has an identity of its own and content related to its ultimate goal.

4) The subgoals of family life education leading to the ultimate goal are:

(a) to help people of all ages and both sexes understand themselves and others in terms of physical growth and development, emotions and behavior, and social interaction.

(b) to help people understand and adjust to their sexuality.

(c) to give people of all ages and of both sexes at appropriate stages in their life cycles true understanding concerning marriage and the family.

(d) to provide for both sexes some mastery of the various 
skills (family problem solving, decision making, and interpersonal relations) essential to family living (Avery and Lee, p. 32).

The working definition used in Avery's survey was:

Family life education involves any and all school experiences deliberately and consciously used by teachers in helping to develop the personalities of students to their fullest capacities as present and future family members--those capacities which equip the individual to solve most constructively the problems unique to his family role (Avery and Lee, p. 27).

Thus, the specific focus would seem to be an education for effective family functioning.

Though the writer has read many definitions by leaders in the field, such as those by Force, ${ }^{32}$ Luckey, ${ }^{33}$ Somerville, ${ }^{34}$ and Frank (1959, p. 73), the Avery definition is quoted and referred to extensively in the literature of the field and therefore will be the definition for the purpose of this study.

The primary concern of this writer lies with the incorporation of family life education into the curriculum of the public educational

32 Elizabeth S. Force, "Family Life Education 1970: A Regional Survey, "The Family Coordinator, XIX, No. 4 (1970), p. 295.

33 Eleanore B. Luckey, "Education for Family Living in the Twentieth Century, "Journal of Home Economics, LVII, No. 9 (1965), p. 686 .

34 Rose M. Somerville, "The Relationship Between Family Life and Sex Education, "Journal of Marriage and the Family, XXIX, No. 2 (1967), p. 374 . 
system and the resulting benefits which can be received by those persons participating in such curricula. A corollary interest is the exposure of social work practioners to this preventative intervention approach.

\section{THE IMPORTANCE OF FAMILY LIFE EDUCATION}

Much has been written about the ailments of today's society. As a part of this, there has been much discussion concerning the problems experienced by the family and its members. Some of these problems are listed below:

The rising divorce rate.

The number of children affected by divorce.

The increasing number of alcoholics and drug abusers.

The increase of personal bankruptcies.

The increasing venereal disease rate.

The increased occurrence of illegitimate births.

The rise of mental illness.

The increased rate of juvenile delinquency.

The tremendous frequency of maladjustment in heterosexual relationships. 35

${ }^{35}$ William M. Smith, Jr., "Family Life Education--Who Needs It?" The Family Coordinator, XVII, No. 1 (1968), p. 55; and Frank W. Welch, "Pooling Resources for Family Life Education, "The 
In view of the above, the need for family life education is formidable. Recognizing the magnitude of the problem, the National Council on Family Relations established a task force (the National Commission on Family Life Education) to examine specific needs. In its report, the task force identified several significant and specialized areas of family life education as follows: interpersonal relationships; self-understanding; human growth and development; preparation for marriage and parenthood; child rearing; socialization of youth for adult roles; decision making; sexuality; management of human and material family resources; personal, family, and community health; family-community relations; and the effects of change on cultural patterns. 36

In his State of the Union message delivered on January 20, 1972 , President Nixon reaffirmed the importance of the family when he said, "We believe in the family as the keystone of the community and we believe in the community as the keystone of society. ${ }^{37}$ The

Family Coordinator, XVII, No. 4 (1968), p. 293; and Edgar E. Stern, "Family Life Education: Some Rationales and Contents," The Family Coordinator, XVIII, No. 1 (1969), p. 39.

${ }^{36}$ Report of the National Commission on Family Life Education, National Council on Family Relations, "Family Life Education: Principles, Plans, Procedures, "The Family Coordinator, XVII, No. 3 (1968), p. 211.

37 Richard M. Nixon, "State of the Union 1972," The Oregonian (Portland, OR, January 21, 1972), section 3, p. 37. 
President's statement is indicative of the national attention given to the family.

It is apparent that persons from pre-school to college age need family life education. The home has traditionally been the vehicle for providing this information and experience. However, the contempo:rary approach is one wherein the school, home, church, and community work together to provide a consistent plan in which each share in the responsibility of providing this learning. ${ }^{38}$ Alfred Adler, as quoted by Lowe, felt that the school had a unique position in society that allowed it to ameliorate the mistaken styles of life learned in the family. Furthermore, he believed it was the schools responsibility to prepare the child's adjustment to life so that he could be himself and be productive in his society. ${ }^{39}$ In this vein, the words of Horace Mann are very appropriate when he said, "Education, if it is to mean anything, must teach us how to live. " 40 The teaching of family life education by the school is a necessary reaction to the problems

${ }^{38}$ Elizabeth McHose, Family Life Education in School and Community (New York: Teachers College, Columbia University, 1952), p. 39.

${ }^{39}$ Raymond N. Lowe, "Parent-Teacher Education Through Family Counseling, "The Family Life Coordinator, XI, No. 4 (1962), p. 87 .

${ }^{40}$ American Social Health Association, Family Life Education Resource Guide Grades 1-12 (New York: American Social Health Association, 1958), p. 1 . 
encountered by society's members. The next chapter, which focuses on the development of the family life education movement, will also review the social forces affecting the family and thus contributing to the growth of this social movement. 
Industrialization and urbanization are social forces that have had and continue to have a marked effect on the structure and function of the family. "Most sociologists trace major changes in the American family system to the Industrial Revolution and the consequent urbanization of society. " 1 Notable changes in the traditional family brought about by the Industrial Revolution were: increased mobility, both physical relocation and class-differential mobility; the creation of a value structure based on achievement; job specialization that statistically precludes an individual being able to obtain a job for a kinsman; and systems of agencies and organizations to handle problems that were solved in the kin network prior to the Industrial Revolution. ${ }^{2}$ The increase of technology and the inventions accompanying the Industrial Revolution had some additional influences on the family. People became aware of their surroundings and what was happening to

${ }^{1}$ Gerald R. Leslie, The Family in Social Context (New York: Oxford University Press, 1967), p. 63.

${ }^{2}$ William J. Goode, "Industrialization and Family Sturcture," in A Modern Introduction to the Family, ed. by Norman W. Bell and Ezra F. Vogal (revised ed.; New York: The Free Press, 1968), p. 115. 
them and their countrymen. New methods of communication were developed and an array of mass media began to have a significant influence the lives of Americans. Americans began to spend more money on movies, newspapers, and magazines and as a result, the family felt the influence of the world.

Along with the increased technology came the expansion of knowledge. The first doubling of knowledge from the birth of Christ took until 1750. By 1900 , the second doubling had taken place. The third doubling had occurred by 1950. And by 1970, we had increased the amount of knowledge that man had at the time of Christ's birth by 64 times. The last doubling had only taken four years. ${ }^{3}$ The effect on the family is well represented by McLuhan when he says:

The Family Circle has widened. The worldpool of information fathered by electric media--movies, Telstar, flight--far surpasses any possible influence mom and dad can now bring to bear. Character no longer is shaped by only two earnest, fumbling experts. Now all the world's a sage. 4

As noted above, the family structure was changing as a consequence of the social forces influencing the family. In more recent times, the complicated, complex and rapidly changing family needed help to keep up with and cope with these changes.

${ }^{3}$ Michael J. Kami, "Planning for Change with New Approaches," Social Casework, LI, No. 4 (1970), p. 209.

${ }^{4}$ Marshall McLuhan, The Medium is the Massage (New York: Random House, Inc., 1967), p. 14. 
As the Industrial Revolution expanded, the rights of women became a topic of national discussion and organization. For example, in 1848, the Women's Rights Convention was held to discuss social, civil, and religious conditions as well as the rights of women. ${ }^{5}$ In 1869, two national organizations for women's rights were formed. They united into one body in 1890 and were called the National American Woman's Sufferage Association (Scott, p. 103).

The woman of those times reaped the benefits of the Industrial Revolution in such a fashion that her duties in the home were not as strenuous nor as time consuming. Moreover, compulsory education laws gave her increased free time so that she was able to participate in activities outside of the home. During the $1870^{\prime}$ s and $1880^{\prime} \mathrm{s}$ women's clubs formed for cultural, social, and social reform activities. By the late 1800's, women's clubs began to unite and in 1889 the General Federation of Women's Clubs was formed (Scott, p. 105).

The women's struggle for equality brought changes in their education, patterns of work, role in American society and views on family life. For example, women were no longer forced to marry because of economic need; divorce laws were liberalized; families consisted of fewer children; and women began to work out of the

${ }^{5}$ Anne Firor Scott, ed., The American Woman (Englewood Cliffs, New Jersey: Prentice-Hall, Inc., 1971), p. 5. 
home. ${ }^{6}$ All of these changes were made explicit by the nineteenth Constitutional Amendment which gave women the vote. Thus, the family was undergoing changes both as a result of urbanization and the Industrial Revolution and as a consequence of the sufferage movement. In summary, the Industrial Revolution, urbanization, and the emancipation of women changed the family's way of life. The profound changes in the structure and function of the family quite naturally brought about a deep concern for the adjustment problems of family members. The family life education movement, no doubt had its beginnings as a result of these concerns.

\section{BEGINNINGS}

The actual dating of the beginnings of any movement is difficult to pinpoint. As Hudson states, ". . its emergence is usually the result of a multiplicity of factors operating within the totality of a social matrix. $" 7$ In discussing the emergence of a social movement Folsom states that when a social problem arises and is recognized, it then becomes defined and discussed.(p. ). People then organize to think about and act on the problem. In the process of organization and focus

${ }^{6}$ Robert E. Riegel, American Women (Rutherford: Farleigh Dickenson University Press, 1970), p. 131 .

7 John William Hudson, "A Content Analysis of Selected Family Life Education Textbooks Used at the Secondary Level, " (unpublished Ph. D. dissertation, Ohio State University, 1956), p. 2-3. 
on a problem, a movement is set into operation (Hudson, p. 47).

Burgess has defined the family life education movement as, "The work of organizations devoted to assisting in the solution of the problems of children, marriage, and the family. . ." 8

The development of the family life education movement has been shaped by many organizations which were concerned with some aspect of the family and family life. Locke and Burgess state that the development of these important organizations has proceeded through four stages. They are:

1) The formation of specialized agencies to deal with different problems of the family.

2.) A growing realization that the specialized problems have vital ties with the total family.

3) The redefinition of the problem in the context of its meaning in terms of family relations as a whole.

4) Persons and agencies who work with the family were integrated into conferences and councils which seek to achieve a unification of the family life education movement. ${ }^{9}$

${ }^{8}$ Ernest W. Burgess, Harvey J. Locke, and Mary Margret Thomas, The Family from Traditional to Companionship (4th ed:; New York: Van Nostrand Reinhold Company, 1971), p. 590.

9

${ }^{9}$ Ernest W. Burgess and Harvey J. Locke, The Family from Institution to Companionship (New York: American Book Company, 1945), p. 736. 
The formation of various organizations whose growth and development contributed to the family life education movement is examined in an analysis of the last half of the nineteenth century and the first quarter of the twentieth century. This reveals the multiplicity and interrelatedness of factors within the social matrix that contributed to the development of the family life education movement. The remainder of this chapter will examine those components influencing its creation.

\section{COMPONENTS}

\section{$\underline{\text { Parent Education Movement }}$}

Kerckhoff states that by the $1880^{\prime}$ 's there was some movement toward a parent group organization whose attention was focused on child management. 10,11 In 1888, the Society for the Study of Child Nature was established. It grew out of the interests of parents in obtaining and making available the most recent scientific knowledge relevatnt to the rearing to their own children (Christensen 1958, p. 14). In 1924, the name was changed to the Child Study Association of America. Later, its focus became more family oriented as it stressed

${ }^{10}$ Richard K. Kerckhoff, "Family Life Education in America," in Handbook of Marriage and the Family, ed. by Harold T. Christensen (Chicago: Rand McNally and Company, 1964), p. 883.

${ }^{11}$ See Orville G. Brim, Education for Child Rearing (New York: Russell Sage Foundation, 1959), pp. 323-325 for a discussion of relevant historical developments in parent education prior to the $1880^{\prime} \mathrm{s}$. 
the training of parent education leaders and developed family life education programs (Lurie, p. 246). Originating from this broad concern for children, another organization was founded in 1896 and called the Congress of Mothers. Its purpose was to bring together groups of mothers to study the child and learn how to become better parents. In 1924, it changed its name to the National Congress of Parents and Teachers (Burgess and Locke, p. 733). As indicated in this name, it was a cooperative organization between school and home and its focus broadened to promote parent education and family life education in the schools. As an outgrowth of this came two significant changes. One was the development of the visiting teachers program in the schools. Thus the work of truant officers who were charged with enforcement of compulsory education was changed to that of home visitors who tried to see the child and his problem in terms of the total family situation. The second development was the organization of departments of child study. The teachers (called adjustment teachers) in these departments studied the child's total situation and then prescribed and recommended individualized treatment programs (Christensen 1958, p. 14, 15). Both the Child Study Association of America and the National Congress of Parents and Teachers were evidence of the concern parents had for better methods of rearing their children. Although not totally separate from other social betterment movements, the trend of parent education came first and is a special 
movement of its own.

Parent education was firmly established by 1929 and in that year the National Council on Parent Education was formed. This was a council of public and private agencies involved in parent education which held workshops and institutes for parent education leaders (Christensen 1958, p. 18). It was disbanded in 1938 due to a lack of funds, but before its demise it too had contributed to the family life education movement (Brim, p. 332). As noted earlier, the emergence of social movements are the result of many factors operating in a current social milieu. Though several start during the same period some flourish while other disappear. For example, the parent education movement was followed shortly by the home economics movement. The latter has continued to flourish while the former exists within other movements.

\section{Home Economics Movement}

As an apparent reaction to urbanization, a home economics movement began in the late 1800's. By 1908 this movement formed its first national organization, the American Home Economics Association. The members of this organization wanted to provide education which was tailored to suit the peculiar needs of women in a rapidly changing culture. Its objectives were to improve the conditions of living in the home, the institutional household, and the community 
(Hudson, p. 4). The efforts of the Association and its programs eventually placed increased emphasis upon the human factor in social and family relations. When the Smith-Lever Act in 1914 established the Cooperative Extension Service in the Department of Agriculture (this was a joint federal-state program) (Brim, p. 326), the close ties between home economics and the Extension Service led to funds being made available to promote training and research designed to improve family life (Kerckhoff 1964, p. 882). Between 1926 and 1935 Association representatives held conferences in every state to encourage teachers to develop work in the area of child development. Over time its activities and programs and the home economics movement became a very active part of the family life education movement. However, not all of the movements found financial support from the federal government. Such was the case for the social hygiene movement.

\section{Social Hygiene Movement}

The concern for social hygiene had its beginnings as a result of an awareness of the problems related to venereal disease and prostitution. The American Society of Sanity and Moral Prophylasix, established in 1905, and the American Federation of Sex Hygiene, founded in 1910, marked the growing interest in sex education. ${ }^{12}$ In 1914 ,

${ }^{12}$ Michael Dennis Ryan, "An Evaluation of Opinions of Selected Students, Parents, and Professional Persons Concerning Curriculum 
these two organizations merged to form the American Social Hygiene Association. ${ }^{13}$ This clearly identified the growing interest in sex education. The Association was organized to foster sex education and to prevent venereal disease and prostitution. These objectives were later expanded to include programs that advance family life education. Thus, the Association was active in: (1) training educators and community personnel to handle the family life education aspects of their work; and (2) working with schools, colleges, and communities in furthering programs of family life education (Kerckhoff 1964, p. 883). In 1960, the Association changed its name to the American Social Health Association. Like the American Home Economics Association, the American Social Health Association changed and enlarged its perspective to include the total family and the forces affecting its functioning.

\section{Child Development Movement}

Another of the multiplicity of influences which contributed to the family life education movement was the child development movement. The beginnings of this movement, like others, is not easily dated.

Content for Instruction in Family Life and Sex Education at the Junior High Level, " (unpublished master's thesis, University of Washington, 1969), p. 10 .

${ }^{13}$ Lester A. Kirkendall and Roger W. Libby, "Trends in Sex Education, "in The Individual, Sex, and Society, ed. by Calfred B. Broderick and Jessie Bernard (Baltimore: The Johns Hopkins Press, 1969), p. 5 . 
The reader will recall that the parent interest groups which were forming in the 1880's were concerned about child management. He will recall, too, that the Child Study Association of America, formed in 1888, and the National Council of Parents and Teachers was established in 1896. However, as mentioned above, the work of Hall during the late $1880^{\prime} \mathrm{s}$ and $1890^{\prime} \mathrm{s}$ is considered to mark the start of the child development movement.

During this period parents were eager for knowledge and were alarmed by the lack of scientific information about children. As a result, a new field of psychology focusing on the development of the child rapidly grew into a field of study. In his analysis of the beginnings of child development and family life education Franks states that many persons believed the care and training of children should be guided by scientific knowledge and,

Never before had the re been such a widespread and sustained effort to study the development of children and to communicate what was being found by investigators and clinical students to parents and teachers; all predicated on the belief that there was little dependable knowledge in the field. 14

While these developments were growing, other ideas were beginning to appear.

Around the turn of the century the work and writings of Sigmund

${ }^{14}$ Lawrence K. Frank, "The Beginnings of Child Development and Family Life Education in the Twentieth Century, "Merrill-Palmer Quarterly, VIII, No. 4 (1962), p. 211. 
Freud began to have an influence on America as it did the rest of the world. With the publication of his first great work, The Interpretation of Dreams, in 1900, and then in 1901 with Psychopathology of Everyday Life, his theory of the dynamics and structure of personality were brought to the attention of physicians and scientists throughout the world and greatly influenced their understanding of children, youth, and adults. Freud and his contemporaries had a powerful effect on those asking for and looking for scientific data concerning the child. The development of Freud's psychoanalytic theory contributed to the growing body of knowledge about human behavior and children. 15

In the early 1920's there were only three nursery schools in the United States. In 1920, there were no child research centers or child development centers. By 1925, the first child development center was organized at Teacher's College, Columbia University (Frank 1962, p. 210). Others soon followed. In 1928, a Laura Spelman Rockefeller Memorial Grant established the Washington Child Research Center (now called the National Child Research Center and located in Washington, D. C. ) (Kerckhoff 1964, p. 882). Interestingly, the funds for this center were given to the custody of the American Home Economics Association. The demand for child development research continued and many centers were formed. At Yale, Dr. Arnold Gessel started a ${ }^{15}$ Calvin S. Hall and Gardner Lindzey, eds., Theories of Personality, (2nd ed. ; New York: Wiley, 1970), pp. 31, 32. 
center of child development research. At Antioch College the Fels Fund Center for Child Research was started. In 1934, the Society for Research in Child Development was formed. The Child Development Journal and the Child Development Abstracts which serve those interested in this field of study is published by this latter society (Frank 1962, p. 211). This brief review of the history of the child development movement seems to establish that the cry of parents for more facts about their children and how to care for them and rear them gave fuel to this movement which in turn broadened the parent education movement. Even though parents were wanting more information about children, and society in one sense was responding to that demand, the family as a whole was not being ignored.

\section{Family Service Movement}

The Family Service Association of America was formed in 1911. It was the first organization which was created for the specific purpose of coordinating and integrating activities and programs of both individuals and agencies dealing with the family (Christensen 1958, p. 18). After the administration of relief was assumed by the federal government during the depression, the welfare agencies developed broader and more personal services to meet the family's growing needs. The Association began as the National Association of Societies for Organizing Charities but changed its name in 1919 to the American Association 
for Organizing Family Social Work. In 1930, it became the Family Welfare Association of America, and then in 1946 it became the Family Service Association of America. These changes represent important steps in the evolution of social work services to the family. 16

Another aspect of this movement is the participation of organized religion. Although Jewish, ${ }^{17}$ Catholic, ${ }^{18}$ and Protestant ${ }^{19}$ social service agencies had not been established in their present form at the beginning of the twentieth century, the concept of services to the family were embodied in the very nature of their religious philosophies. Members of the clergy were active in the family life education movement and the national bodies of these religions supported and urged individual churches and their respective agencies to develop family life programs. The preservation of the family and the continuation of its

${ }^{16}$ Muriel W. Brown, "Organizational Programs to Strengthen the Family, "in Handbook of Marriage and the Family, ed. by Harold T. Christensen (Chicago: Rand McNally and Company, 1969), p. 851.

17 William Avrunin, "Jewish Social Services," in Social Work Year Book 1960, ed. by Russell H. Kurtz (New York: National Association of Social Workers, 1960), pp. 338-343.

18 Raymond J. Gallagher, "Catholic Social Services," in Social Work Year Book 1960, ed. by Russell H. Kurtz (New York: National Association of Social Workers, 1960), pp. 136-141.

${ }^{19}$ F. Ernest Johns on and William J. Villaume, "Protestant Social Services, " in Social Work Year Book 1960, ed. by Russell H. Kurtz (New York: National Association of Social Workers, 1960), pp. $441-451$. 
religious educational function, as perceived by Catholic, Jewish, and Protestant faiths, paralleled the family life education movement's efforts to strengthen family life. Each religious body established separate national social sercice coordinating organizations which worked toward the improvement of services to the family. 20

The increasing interest in family life was borne out by the many local, state, and national conferences of people from various fields of specialization who gathered together to discuss and share their common interest in family life education (Kerckhoff 1964, p. 883). One such conference was held in New York City in 1934. It was co-sponsored by the American Home Economics Association, the American Social Hygiene Association, and Teachers' College of Columbia University. This Conference on Education for Marriage and Family Relations served as the model for the formation of a new organization which was to become the most important in the field of family education. Thus, the National Conference on Family Relations was formed in 1938 (Christensen 1958, pp. 18, 19). This brought together in one group: (1) the teachers of marriage and family courses; (2) professional persons who rendered services to the family; and (3) research people from all fields dealing with marriage and the

${ }^{20}$ Rae C. Weil, "Family Social Work," in Social Work Year Book 1960, ed. by Russell H. Kurtz (New York: National Association of Social Workers, 1960), p. 256. 
family. Today this organization is known as the National Council on Family Relations and has many divisions which deal with all aspects of marriage and family life. As the official organization for this field, it publishes the Journal of Marriage and the Family and The Family

Coordinator. These journals report significant research concerning the family and print contributions from the leaders in the field of family life. In 1969, this multidisciplinary organization had approximately 4, 300 members whose primary interests were in such areas and disciplines as: family relations and child development; home economics, marriage and family counseling; the clergy; social work; psychology; medical and paramedical; and many more. 21

In summary, it seems obvious that the above organizations and the movements they represent were related to the various social forces existing at the time. They were not independent of each other and did not develop in isolation. The consequence of these forces and movements working together was the birth of the family life education movement.

During the growth of the family life education movement the parallel development of other movements contributed to its strength. For example, the marriage counseling movement, as solidified by the

${ }^{21}$ Ruth Jewson, "The National Council on Family Relations - Decade of the Sixties, "Journal of Marriage and the Family, XXXII, No. 4 (1970), p. 610. 
establishment of the American Association of Marriage Counselors in 1941, gave added credance to the need for family solidarity and, therefore, was consistent with the goals of the family life education movement. 22 Another example was the mental health movement of the earlier part of the twentieth century. It began with programs to help people learn about mental illness. Later programs were developed that promoted mental health and thusly was working toward strengthening the family (Brim, p. 327). A concluding example of contributions from parallel movements can be seen in the family planning movement. The Planned Parenthood Federation of America was incorporated in 1922. It fought legal repression in its beginning but was able to remain and in doing so established the relevance of family planning to family life and it too contributed to the family life education movement (Folsom, p. 190).

\section{Government Programs}

The evolution of organizations concerned with aspects of the family resulted in the inclusion of these concerns into the structure of the federal government. When the Children's Bureau was established by an Act of Congress in 1912, a victory had been won by those who

22 Gerald R. Leslie, "The Field of Marriage Counseling," in Handbook of Marriage and the Family, ed. by Harold T. Christensen (Chicago: Rand McNally and Company, 1964), p. 920. 
had struggled to incorporate into the Federal Government an agency that would be". . . a spokesman and advocate for all children throughout the nation. 123 One important recommendation by the 1909 White House Conference on the Care of Dependent Children was the formation of a Children's Bureau. The Bureau gathered information on children, formulated this data into the needs of children and served as an advocate to those needs by getting action in behalf of children. ${ }^{24}$ The responsibilities of the Bureau involved examination of the inter related economic, social, health and legal conditions affecting children and their families. Infant mortality, the birth rate, orphanages, juvenile courts, desertion, dangerous occupations, accidents, diseases of children and employment are examples of the areas studied by the Bureau (Eliot, p. 2). By making public their findings in these areas and working for solution to the problems identified, the Children's Bureau became a strong influence in the family education movement.

As a result of the stock market crash in 1929 , the federal government became very active in programs concerning the family. National agencies were working with a sense of urgency as the faltering economy affected American families. The Home Economics

${ }^{23}$ Martha M. Eliot, "Six Decades of Action for Children," Children Today, I, No. 2 (1972), p. 2.

${ }^{24}$ Maurice O. Hunt, "Child Welfare," in Social Work Year Book 1960 , ed. by Russell H. Kurtz (New York: National Association of Social Workers, 1960 , p. 152. 
Education Service which was transferred to the U.S. Office of Education in 1933 decided to work with one community in each of four states that shared with their belief in family life education. Their view was that:

. . an educational program that aids in making family life function more effectively, is of prime importance to society and that every person who is a member of a home should have an opportunity for an expanding educational experience dealing with this phase of his life, from early childhood into adulthood and parenthood. 25

The Great Depression was the cause of social and economic distress throughout the nation. In 1933, President Roosevelt began his New Deal program to put life back into the economy and to meet the needs of Americans. The Federal Emergency Relief Administration was established in 1933 and was funded with $\$ 500$ million for economic relief (Ferguson, p. 74). In 1935, the Works Progress Administration replaced the Federal Emergency Relief Administration. It made trained personnel available to help groups interested in child behavior. Much of the parent education expansion in the public schools began with the Works Progress Administration (Brim, p. 333). In 1935, the Social Security Act was enacted by Congress. It provided for a national program of old-age insurance, unemployment insurance, and made

${ }^{25}$ Rose M. Somerville, "Family Life and Sex Education in the Turbulent Sixties, " Journal of Marriage and the Family, XXXIII, No. 1 (1971), p. 17. 
funds available for various public-health and state welfare projects. 26 These New Deal programs contributed to the family life education movement as it worked to aid the economic and social crisis that individuals and families faced during the depression. Involvement of the federal government in the family life education movement brought federal agencies onto the scene and added another dimension to the growing list of active participants.

The organizations and agencies discussed above often cooperated in joint programs to further the common goals they shared.

\section{Additional Influences}

The family life education movement was strengthened and broadened by several programs jointly sponsored by various national organizations. For example, the Rocky Mountain Project was conducted by the American Social Health Association and the National Congress of Parents and Teachers between 1959-1961. This project covered four states: Utah, Nevada, Arizona and New Mexico. The specific objectives were aimed at strengthening the family and enabling family members to understand each other and participate in a

${ }^{26}$ Robert H. Bremner, From the Depths (New York: New York University Press, 1956), p. 264 . 
successful family life together. ${ }^{27}$ Both community and school programs were utilized to meet these goals. Another example was the family improvement programs shared by the American Home Economics Association and the Department of Agriculture's Cooperative Extension Service (as discussed above).

A most significant contribution came from two private funding sources. One was the Laura Spelman Rockefeller Memorial Fund whose financial aid to the child development and parent education movements, as discussed above, enabled many programs, institutes, and agencies to train parent education leaders, conduct child development research, and offer services to families. In doing so the Fund contributed to the family life education movement (Kerckhoff 1964 , p. 882).

The second was the E. C. Brown Trust. Established by the will of Dr. Ellis C. Brown, it administers funds to be used to further family life and sex education. The pioneering work of the Trust in the development of sex education films and courses in family life are wellknown in the field. It offers continued leadership in the present as it sponsors publications and has an extensive library of family life materials. 28

27 National Congress of Parents and Teachers, The Story of the Rocky Mountain Project (Chicago: National Congress of Parents and Teachers, 1964), p. 3 .

${ }^{28}$ Curtis E. Avery, Meet the E. C. Brown Trust Foundation (Portland, Oregon: E. C. Brown Trust Foundation), pp. 1-12. 
As any social movement strives for the accomplishment of its social goals a strategy utilized is the incorporation of related edicational content into the schools. The family life education movement was no exception to this pattern.

\section{Family Life Education in the Educational System}

Educational objectives have changed since the time when education was first viewed as a training process in certain arts and skills not required by the masses for a priviledged minority. Thus, status was the primary purpose of education. However, as society became more complex, the relevance of a literate populus became evident. As a result, education adopted the curriculum so commonly referred to as the "3 R's." Society viewed literacy as a tool to accomplish efficiency. Efficiency became the objective and reading, writing, and arithmetic became the educational means. However, critics questioned: (1) the validity of the objectives; namely, efficiency; and (2) whether or not the content would really prepare the student for a happier, more successful life than he would have been otherwise. This criticism brought the educational objectives back to reality (Folsom, p. 3-5). The efforts of the Progressive Education Association, as discussed above, attempted to change and improve education and by so doing, improve society as well. The educational objectives advocated by it were life objectives to be gained rather than just 
subject matter to be taught (Folsom, p. 68, 70).

Higher Education. The influence of the child development, parent education, and progressive education movements each gave some of the impetus needed for family life education to develop in the schools. In 1924, Ernest R. Groves taught the first college course in family life education at Boston University. He even wrote the text for the course. (He taught the same course at North Caroline in 1927 after leaving Boston University.) His course, titled 'Marriage Preparation, "was not the first that dealt with the family. Before 1924, there were 22 colleges offering courses in the family, 15 of those before 1920 and 4 as early as 1910. However, these courses concentrated on the family as a social institution and examined historical studies of the family, whereas Groves' course emphasized family life preparation (Kerckhoff 1964, p. 884).

There were very few courses such as the latter prior to 1930. However, during the $1930^{\prime}$ 's there was a growing belief that education for marriage and the family could aid both individual happiness and social welfare (Kerckhoff 1964, p. 884). Departments of Sociology and Home Economics were the original sources of such courses; but by 1936, social science, religion, and psychology departments were offering courses in family life (Christensen 1958, p. 23). Also, departments of Family Relations began to form and offer their own courses in family life education. The number of courses offered in 
marriage and the family grew rapidly. A survey completed in 1948 1949 , of 1,270 colleges and junior colleges found that 632 had at least one marriage education course in their curriculum. ${ }^{29}$ A study by Landis showed that during the academic year 1956-1957 of the 630 colleges out of the 768 responding, offered 1,027 courses to 77,000 students and involved 1,000 professors. Since less than half of Landis' sample responded, one can assume that these figures do not represent the actual experience in the country (Kerckhoff 1964, p. 885). However, it does point up in itself the tremendous growth of such courses in higher education. As a matter of fact this trend has developed to the extent that there has evolved a crystalization of common subject matters. For many this has meant that family life education has become a field in its own right, perhaps even a discipline (Christensen 1968 , p. 24). Higher education responded to the needs of its constituency before the secondary or elementary levels did so.

Secondary Education. Family life education was slower to take hold in secondary schools. There are two identified reasons for this phenomenon. First was the lack of trained personnel to teach the classes. And second, the most important, was the resistance from the local communities to approve of the teaching of such courses.

${ }^{29}$ Henry A. Bowman, "Collegiate Education for Marriage and Family Living, "The Annals of the American Academy of Political and Social Science, CCLXXII (November, 1950), pp. 149, 150. 
Initially, the only courses taught in secondary schools which were remotely related to family life were those that were organized in the form of the homemaking and domestic sciences (Hudson, p. 6). Exceptions existed however, and in 1918, one of the first high school family life education courses was offered in Tulsa, Oklahoma. 30 In 1920, the U.S. Bureau of Education and the U.S. Public Health Service sent out a questionnaire to learn about the frequency of sex education in high schools. The results showed that of the 53 percent responding, of 12,025 high schools, there was much course experimentation but no uniformity of content among the various schools experimenting (Ryan, p. 13, 14). However, only a few high schools had adopted such courses into their curriculum by the middle 1930's and these courses centered on marriage and family living (Hudson, p. 6).

During the 1940's and especially after World War II, the programs had broadened into all areas of family life education and there were many such programs across the nation. Secondary education programs in family life education started as a result of the rapid changes in society and the family itself, the need for democratic alternatives to authoritarian child rearing patterns, and a belief that since other areas of life have responded well to direct education,

${ }^{30}$ William M. Kephart, The Family, Society and the Individual (2nd ed.; Boston: Houghton Mifflin Company, 1966), p. 634. 
family life could also be positively affected (Kerckhoff 1964, p. 887).

In September, 1941, an interesting success story of one such course began in the Tom Rivers High School, Tom Rivers, New Jersey. It was an elective course offered to 11 th and 12 th grade boys and girls. This program was based on the belief that ". . the institution best equipped to launch a responsible, organized program to help youth toward the self-understanding which must precede the building of a stable family is the school. " 31 The Tom Rivers Program drew national attention and contributed to the spread of such courses into other schools.

A 1958 study by Landis of high school level courses in family life education found that they were often required, coeducational, and covered courtship and marriage and offered as a part of social studies curriculum. He also found that the 9 th grade family life education program was less specifically designed for marriage and parenthood and usually dealt with personal adjustment, mental health, understanding oneself and others, and getting along with the family and the opposite sex (Kerckhoff 1964, p. 887). A study of graduates of high school family life education courses in Indianapolis, Indiana by Behlmer in 1961, gave important backing to the relevance of such

${ }^{31}$ Elizabeth S. Force, Teaching Family Life Education (New York: Bureau of Publications, Teachers College, Columbia University, 1962), p. 38. 
courses and as a result firmly established these courses into the cur riculum. ${ }^{32}$ Family life education was adopted by higher education and secondary education prior to elementary education even though the latter was perceived to be the logical starting point.

Elementary Education. Elementary schools were the last of the public educational setting to adopt a family life education curriculum. During the 1940's and the 1950's, elementary schools incorporated an emphasis on helping children improve their relationship with the other members of their family, some sex education as it deals with menstruation, reproduction, and other biologically oriented subjects into their curriculum. Family life curriculum in elementary schools has been applied on the basis of two principles. First, it should be diffused throughout the curriculum rather than condensed into a separate course. And second, the family life education curricula that is offered should be geared to the child's developmental stage (Kerckhoff 1964 , p. 888). This has been a guideline for decision about family life education content for all academic levels, but is most applicable in decision making concerning subject matter offered in an elementary school.

In 1941, the American Association of School Administrators recommended that sex education be included in the curriculum of elementary schools. Further evidence of the concern for the delivery

${ }^{32}$ Reuben D. Behlmer, Family Life Education Survey: A Report (Indianapolis: Indiana State Board of Health, 1961), p. 9. 
of family life education came in 1948, when the National Conference on the Education of Teachers went on record in favor of sex education as being a part of the curriculum for all teachers. ${ }^{33}$ The elementary school was viewed as the logical starting place for family life education. The contributing influences that resulted in the adoption of family life curriculum into elementary education can be traced back to the body of knowledge concerning child development and the importance placed on the child's early experiences for future life patterns, and. attitudes (McHose, p. 34). The lack of trained personnel and the resistance by local communities thwarted the incorporation of family life education into elementary schools until the above influences could not be denied any further.

A thorough review of the family life education movement literature has failed to reveal a specific date as to the beginning of family life education in elementary schools. However, Somerville (1971, pp. 26, 27) and Kerckhoff (1964, pp. 887-891) in their analysis of elementary family life education make no reference to it prior to the 1940's. As was true for higher education and secondary education the inclusion of family life education into the elementary curriculum had its beginnings on a limited, experimental basis. A report of the

${ }^{33}$ Helen Manley, Family Life and Sex Education in the Elementary School (Washington, D. C.: National Education Association, 1968), p. v. 
subcommittee on Preparental Education of the 1930 White House Conference on Child Health and Protection revealed that prior to this conference, there was limited experimentation at the elementary level with courses and units of family life education and called the attention of educators to the importance of such education for home and family life via the schools. 34

The admission of family life curriculum into the elementary school was not firmly established until the secondary and higher education levels had successfully demonstrated to the public the need for its existence. This process created more support for family life education in the elementary school and also provided for the training of personnel within elementary education to teach this curricula.

\section{SUMMARY}

The family life education movement began with the social and cultural changes of the nineteenth and twentieth centuries. Parents of this time were concerned about the effects of these changes on their children. They organized informally at first and formally later in their attempt to find scientific answers to their questions. A growing body of knowledge concerning the child's early development as

${ }^{34}$ Report of the Subcommittee on Preparental Education, The White House Conference on Child Health and Protection, Anna E. Richardson, Chairman, Education for Home and Family Life Part I (New York: Century Press Company, 1932), p. 5. 
contributed by Freud and his contemporaries and the theories of psychoanalysis as well as the research from the child development research centers of the 1920's and $1930^{\prime}$ s added to this knowledge. Higher education, at first, and then secondary next and finally elementary education responded to the need for the inclusion of direct educational experiences for the student concerning himself and his present and future family. During this time, there were many organizations whose active participation broadened and deepened the path of the movement. The federal government and local communities were also active in efforts to augment present programs and to begin new ones. These efforts sustained the relevance of education for family life. The movement grew from its home economics and parent education beginnings and came to include the disciplines of sociology, psychology, religion, social science, anthropology, political science, and biology. Its growth may have established it as a discipline in its own right.

Family life education has been referred to by various names. Among them are education for marriage and the family, family relations, sex education, family living, and others. The emphasis may vary but the focus is still on the family and how to educate its members for a more productive, meaningful, and successful life as a person and as a family member. 
At the present time, family life education is no longer a movement, but an established part of everyday life. However, it does not go without its opponents and has received much criticism. The opposition to family life education is the problem which this study attempted to examine. The remaining chapters will deal with the specifics of this study. 
CHAPTER III

\section{METHODOLOGY}

Possibly the least controversial statement that could be made concerning family life education is that it is a controversial subject. Volumes have been written in various professional journals about this topic and interest has been fanned by the mass media. The controversy over sex education has rocked the American schools to the point that the writer questioned the desirability of undertaking the study of a charged public issue. However, it was not clear in the writer's mind if this topic has been examined with the objectivity and calm which it requires. Therefore, in consideration of the emotionalism of those opposed to the teaching of sex education in the schools and the recognized lack of valid information on the part of the public concerning the total family life education curriculum, as opposed to sex education, the writer attempted to examine, for the purpose of this study, the following variables:

1): Parental knowledge concerning one school's family life education curriculum; and

2) Parental attitudes relative to specific topics in a family life education curriculum. 
Thus, the purpose of this study was to test the hypothesized relationship between these two variables as indicated below:

Hypothesis I. Parents who have correct information concerning what the school teaches their children in its family life education curriculum will be in agreement with the school's responsibility for teaching such topics.

Hypothesis II. Parents who do not have correct information concerning what the school teaches their children in its family life education curriculum will not be in agreement with the school's responsibility for teaching such topics.

The decision having been made about what data to be collected the writer then had to make a judgment regarding where to obtain his data. A primary consideration was the feasibility of an extensive sampling within the restricted time limits afforded by school and university regulations. A second consideration was the factor of principal permission which would be required to carry out the study. It seemed that the process of obtaining permission from several principals might bog down the study before it was started. Therefore, the writer decided to collect data from a random sample of parents, all of whose children attended one specific school. A third consideration was the factor of geography. The Portland School District seemed to be the most feasible to the writer. This school district uses a decentralized administrative system involving three areas. 
The writer, therefore, randomly selected Area II and approval for this research was granted by the area administrator. An elementary school was selected by the writer as the setting of this study for the following reasons:

1) It is the writer's conviction that family life education should be the educational experience of children from the time of entrance into the public school system as well as in the church, home, and community; and

2) The experiences and attitudes of parents regarding family life education as conducted for their children in the elementary school may shape their attitudes concerning this curricula being taught in other educational levels.

The selection of the specific school was made on the basis of an interest in this study by the principal. The sample was drawn from the 342 families which had children enrolled in Jason Lee Elementary School ${ }^{1}$ at the beginning of January of the 1971-1972 academic school year. Forty families were randomly selected from an alphabetical listing by the use of a table of random numbers.

\section{SELECTION AND CONSTRUCTION OF INSTRUMENTS}

In trying to devise an effective instrument for gathering the

${ }^{1}$ For a description of Jason Lee Elementary School, the reader is referred to Appendix $C$. 
necessary data several factors seemed necessary to consider. Among them were:

1) The instrument should provide an accurate assessment of the respondent's knowledge of the family life education curriculum without introducing biases.

2) The instrument should assess parental feelings and attitudes regarding specific content areas of the family life curriculum as well as their overall reactions to this program.

3) The instrument should be realtively simple in construction to allow for ease of response from a potentially varied parental group.

4) The instrument should be designed so as to allow for ease of quantitative analysis of the data.

In view of the above criteria the writer concluded that a questionnaire would be the best instrument for use in this study.

Inherent in the use of questionnaires are several problems. The greatest of these is insuring the return of the questionnaire. Related to this are: clarity of instructions; simplicity of questions; time required to answer the questions; and nature of the questions, specifically their degree of personality.

At the outset, the writer thought that an open-ended questionnaire was the best method to accurately assess the fellings of the 
respondents and to allow for free expression of their beliefs. The questionnaire used in the pre-test contained seven multiple-choice questions and fourteen open-ended questions. The final questionnaire used in this study and the instrument used in the pre-test had very little in common and for that reason the pre-test form will not be analyzed. However, a discussion of the pre-test will disclose the need for a different form of that questionnaire.

\section{The Pre-Test}

Arrangements for a pre-test were made in a school district in a city in another part of the state. A school principal who was favorable to family life education agreed to assist the writer with the pre-test. The writer requested that the principal select two families in each of the three following categories:

1) In favor of family life education in the schools.

2) Opposed to family life education in the schools.

3) Opinions concerning family life education in the schools unknown.

This request was made so that the pre-test sample would be heterogeneous in opinion and, therefore, give insight into changes needed in the questionnaire based on different perspectives. Accordingly, the pre-test sample consisted of six families who were willing to participate. 
A cover letter accompanied the questionnaire that was mailed to these parents. The writer then contacted the parents, picked up the questionnaires, and interviewed the parents concerning the instrument.

In the follow-up interview the writer attempted to obtain answers to the following questions:

1) Were there any questions that you did not understand?

2) Do you have any suggestions as to how the questions can be changed to make them easier to answer or understand?

3) Do you feel the questionnaire was biased one way or another?

4) What did you like and dislike about the questionnaire?

5) Did the questions bore you and did you find the questionnaire a difficult task to complete? How long did it take to answer all the questions?

6) What were your thoughts while answering the questions?

7) Any further comments, criticisms, or reactions that you have not already shared with me?

The pre-test indicated that the questionnaire was too long and took too much time to complete (about 25 minutes on the average). Additional information indicated that if the principal had not contacted the parents, some would not have completed the questionnaire because of its design. (The response rate was 83 per cent [N=5].) 
However, the most dramatic result was that the data collected was almost impossible to use for analysis of the hypotheses to be tested. Consequently, the pre-test questionnaire was discarded and a new one was developed.

Instrument I - Parental Assessment Questionnaire (PAQ)

In constructing a new instrument the writer was able to draw upon the expertise of the School of Social Work's research consultant and the students in one of his courses. Out of this the writer developed a matrix format that would allow the subjects to respond to a listing of topics that would be contained in a family life education curriculum. The use of the matrix permitted:

1) The exclusion of any unfamiliarity with the meaning of "family life education" as it had been used in the former questionnaire.

2) The presentation of the topical matter in explicit form to which the parents were previously asked to respond to by using the word "family life education."

3) The prevention of bias from the use of the words "family life education."

4) The ease in quantitative analys is of the data collected.

5) A simplified manner of response.

6) The completion of the questionnaire in a brief amount 
of time.

The topics listed in the matrix were selected by the writer in a process of extrapolation from the suggested content segment of two family life and sex education curriculum guides. ${ }^{2,3}$ Nine topics were identified and listed in the matrix. They were: personal growth and development; getting along with others; about society; about one's family; preparing for one's own family; animal reproduction; human anatomy; human sexuality; caring for yourself and your body.

Three questions were used in the matrix and each one related to the nine topics cited above. These questions were as follows:

1) Do you feel that the topic should be taught to your child by the school?

2) Is the topic being taught to your child by the school?

3) If the school does teach this topic, do you feel it has been helpful to your child?

Questions one and three were used to measure the parental feelings and attitudes variable. Question two assessed the parental knowledge variable. For each question an extreme range of responses was

${ }^{2}$ Ester D. Schultz and Sally R. Williams, Family Life and Sex Education (New York: Harcourt, Brace, and World, Inc., 1968), pp. $49-128$.

${ }^{3}$ H. Frederick Kilander, Sex Education in the Schools (New York: The Macmillan Company, 1970), pp. 36-82. 
offered the parents. Also included was a response for indicating uncertainty.

The writer thought that parents would need the opportunity to respond in their own words. Therefore, question four was openended. It allowed explanation of the feelings variable as measured in question one and also provided a mechanism to check the consistency of the respondent's answers. Question five was a forced-choice question which was included to measure specific knowledge held by the parents and to yield additional data concerning this variable. These two questions were apart from the matrix. In order to allow for completion of the questionnaire, space was provided for any additional comments that the parents might have to make (see Appen$\operatorname{dix} A)$.

The writer's original plan was to seek permission to use the school's personal files on each of the families selected so that information such as age, occupation, religious preference, and education could be used in the analysis of data. However, because the files do not contain all of this information and because the granting of access to the files raised administrative questions concerning confidentiality, this information was collected from the parents in a separate section of the instrument (see Appendix A). The latter would then be compared with the responses to the previous questions. The unit of analysis for the purpose of this study was the 
response of both parents jointly or as presented by one parent for both. This procedure 4 was explained in the cover letter from the principal and in the follow-up letter from the writer (see Appendix A). Parents were asked to identify who had completed the questionnaire by indicating one of the following: mother, father, or both together.

Instrument II - Teacher Survey (TS)

As previously noted this study attempted to examine knowledge and attitudes of a sample of parents in a selected school. In order to assess the accuracy of their knowledge about the family life education curriculum of the school, an instrument had to be developed which would solicit from the teachers the specific of what was taught in this topical matter. This information would then become the baseline for assessing parent knowledge.

The writer utilized the matrix form (with adaptations) that was developed for the parental assessment questionnaire (hereafter referred to as $P A Q)$. The designing of the teacher instrument to contain precisely the same material as included in portions of the PAQ obviously would permit transferability of patterns of data and allow for comparison of specific facts. The topics used in the matrix

${ }^{4}$ Additional copies of the instrument were provided so that parents who held differing opinions could complete a separate questionnaire if they so desired. 
of the PAQ were also utilized in the teacher survey (hereafter referred to as TS) as were the grades $\mathrm{K}-8$ and a N/A column. The teachers were asked to check the grade or grades to which they taught each topic, or to check the not applicable column if appropriate. Question five of the PAQ was adapted for use in the TS (see Appendix B).

\section{DATA COLLECTION}

\section{Collection of the Parent Data}

An obvious advantage of the use of a questionnaire in this study can be recognized by the reader when he recalls the emotional nature of the subject under investigation. The impersonal nature of a questionnaire was perfectly suited for its use in this study. Also a questionnaire:

1) is less expensive than an interview;

2) requires less skill to administer;

3) is standardized in wording of questions and instructions;

4) creates more confidence in the respondent's answers remaining anonymous. 5

${ }^{5}$ Claire Selltiz et al., Research Methods in Social Relations, (revised ed.; New York: Holt, Rinehart and Winston, Inc., 1959), pp. 238-240. 
On the other hand, realizing that mailed questionnaires are easily forgotten, discarded, and not returned, the writer employed the strategies as suggested by Linsky and Spendlove to maximize the return rate. These strategies are:

1) Emphasize the social value of the research.

2) Personalize the request for participation.

3) Emphasize the need for obtaining each protocol.

4) Assume confidential nature of data handling.

5) Designate target date for returning the questionnaire.

6) Provide addressed, postage-free return envelope. 6

The reader will note in examining the cover letter and the followup letter the writer attempted to emphasize the social value of the research and by having the principal sign the cover letter sought to personalize the request for participation. In addition, school stationery and envelopes were used. In each of the letters the need for obtaining each questionnaire was stressed as was the confidentiality of the handling of the data. Furthermore, the parents were informed as to the target date for returning the questionnaire and were provided with addressed, postage-free return envelopes in the cover letter and the follow-up letter,

${ }^{6}$ Arnold S. Linsky and George A. Spendlove, "Note on an Unusually High Response Rate to a Mail Questionnaire," Journal of Health and Social Behavior, VIII, No. 2 (1967), p. 147. 
The return envelopes were coded so that the writer could monitor the returning of questionnaires and be cognizant of those parents who did not return their questionnaire. This process ${ }^{7}$ allowed for follow-up letters to be mailed to such parents as necessary. The coding of return envelopes was applied to the follow-up phase as well and thus enabled the writer to make personal contact with parents where required. The coded envelope was matched with the parent to whom the questionnaire was mailed and recorded on a master list. The initial return was 30 per cent $(N=12)$. A follow-up letter was sent out after two weeks and it yielded a return of 12.5 per cent $(N=5)$. After one week, in an effort to avoid non-response bias, the writer initiated personal contact with the remainder of the sample. 8 The final response rate was 8.7 .5 per cent $(N=35)$. There were 12.5 per cent $(N=5)$ who did not participate; three of these refused. The latter group stated that the questionnaire was "too personal" and "that's my business" as reasons for not wanting to participate. Of the others not participating, one was lost through attrition and one was mailed

7 The return envelopes were coded by the use of two sets of envelopes; of which twenty were addressed with a pica typewriter and twenty were addressed with an elite typewriter. Twenty eight-cent stamps or lower denomination stamp combinations totalling the required postage were used for each set of envelopes to specifically idenfity the parent to whom the questionnaire was mailed.

${ }^{8}$ See Appendix A for the personal contact procedure utilized in this phase of the data collection. 
but never recieved. The collection of the data took approximately five weeks. From the sample of forty families, thirty-five participated, in this study. Table I indicates the family member(s) who completed the questionnaire.

\section{TABLE I}

PERSONS COMPLETING PARENTAL

ASSESSMENT QUESTIONNAIRE

\begin{tabular}{lcc}
\hline Person & Per Cent & N \\
\hline Mother & 40 & 14 \\
Both Together & 37 & 13 \\
Both Separately & 17 & 6 \\
Father & 6 & 2 \\
Total & $100 \%$ & $\mathrm{~N}=35$ \\
\hline
\end{tabular}

\section{Collection of Teacher Data}

At the time of this study there were twenty-six paid teachers on the staff. Of this number, nineteen were homeroom teachers and the remaining seven were specialty teachers. The special courses taught by the latter group were music, shop, physical education, and home economics; students of several grades participated in the se subjects.

The TS was distributed to all of the teachers with a cover letter 
from the writer. Once again, the tactics of Linsky and Spendlove (p. 146-148) to improve return rates of questionnaires, as cited above, were employed by the writer in this letter (see Appendix B). The TS was sent to the teachers by the use of their respective mail boxes located in the school office and were to be returned to the principal's secretary.

The initial return was 46.1 per cent $(\mathrm{N}=12)$. One week later as a follow-up procedure, the writer requested the principal to ask the teachers to complete and return the TS. Accordingly, a memorandum from the principal to the teachers was posted on the key locker (which is frequently used by the principal to communicate information to the teachers) urging the return of all surveys. This process yielded one survey form (3.9 per cent). After one week, personal contact 9 was initiated with the teachers in an effort to receive all of the surveys. This was accomplished by the writer's attendance of a teacher's meeting and the distribution of additional copies of the TS at this meeting. This netted a return of 15.3 per cent $(N=4)$. The total response rate was 65.3 per cent $(\mathrm{N}=17)$. Table II indicates the teacher assignments of those teachers completing the survey.

${ }^{9}$ See Appendix B for the personal contact procedure utilized in this phase of the data collection. 
TABLE II

TEACHERS COMPLETING TEACHER SURVEY

\begin{tabular}{ccc}
\hline Grade & Frequency & No. Assigned \\
\hline K & 1 & 1 \\
1 & 1 & $1-1 / 2$ \\
2 & 0 & $2-1 / 2$ \\
3 & 4 & 2 \\
4 & $2-1 / 2$ & $2-1 / 2$ \\
5 & $1-1 / 2$ & $2-1 / 2$ \\
6 & $2-1 / 2$ & $2-1 / 2$ \\
7 & $2-1 / 2$ & $1 / 2$ \\
8 & $1-1 / 2$ & $2-1 / 2$ \\
Total & 17 & 2 \\
\hline
\end{tabular}

III. THE NATURE OF THE REPORT

In Chapter I the writer attempted to set forth the past, current, and future status of the family in America. The trends of social work were reviewed and the attention given the family in these various directions was analyzed. The changing role of the schools was also studied. The purpose of this study and the writer's reasons for such an endeavor were discussed. The opposition to family life education in the schools was stated as the problem and the questions to be answered by this study were delineated in this chapter.

The focus in Chapter II was on the family life education movement 
and examined the contributing influences to its creation and development. Specific attention was given to the development of family life education in the schools.

The present chapter describes the methodology for this specific study while Chapter IV will set forth the findings and interpretations of the data. The concluding chapter will examine the implications of this study and raise questions for future research in family life education. 
CHAPTER IV

\section{FINDINGS}

As delineated above two variables were identified for study in this research. They were: 1) parental knowledge concerning the school's family life education curriculum; and 2) parental attitudes and feelings concerning the teaching of specific topics in a family life education curriculum. The hypotheses to be tested postulated a relationship between these two variables as indicated below:

Hypothesis I. Parents who have correct information concerning what the school teaches their children in its family life education curriculum will be in agreement with the school's responsibility for teaching such topics.

Hypothesis II. Parents who do not have correct information concerning what the school teaches their children in its family life education curriculum will not be in agreement with the school's responsibility for teaching such topics.

\section{IDENTIFYING CHARACTERISTICS OF THE SAMPLE}

In the personal data section of the PAQ, parents supplied the following information: age, marital status, ages of children, 
occupation, church affiliation, and education. A normal expectation of parents of elementary school children is that they be relatively young. Forty per cent $(\mathrm{N}=14)$ of the sample fit this expectation (age 35 and under). However, common sense tells us that some parents are older and may have children in high school or of college age as well as in an elementary school. In this study 60 per cent $(N=21)$ of the parents were in this category (age 36 years or above).

One might expect the older parents, as a group, to hold more traditional and conservative values and as a result might be more opposed to family life education than the younger parents. Interestingly, the opposition to any aspect of family life education (as presented by the topics included in the matrix of the PAQ) was equal for each age group. In the younger parent group, 28 per cent $(N=4)$ were opposed to certain topics being taught as were 29 per cent $(N=6)$ of the older parent group.

The family size of the sample ranged from one to six children and the node was three children per family. If the number of children per family were to have any bearing on the parents' attitudes toward family life education in the schools, it would seem that the larger the family the less opposition there would be to these topics being taught. This is supported by the figures illustrated in Table III. 
TA BLE III

FAMILY SIZE AND FREQUENCY OF OPPOSITION TO THE FAMILY LIFE EDUCATION TOPICS

\begin{tabular}{ccc}
$\begin{array}{c}\text { Number of children } \\
\text { per family }\end{array}$ & $\mathrm{N}$ & $\begin{array}{c}\% \\
\text { opposed }\end{array}$ \\
& $\mathrm{N}=34$ & \\
1 & 2 & 100 \\
2 & 10 & 50 \\
3 & 12 & 25 \\
4 & 6 & 17 \\
5 & 2 & 50 \\
6 & 2 & 0 \\
\hline
\end{tabular}

It should be pointed out that the opposition did not constitute a rejection of all the topics. The greatest number of topics to which any parent was opposed being taught by the school was three topics. This was by a parent who had one child.

Support for a family life curriculum might be accounted for by the educational level of those supporting it. As a group, the amount of education obtained by the parents of this sample was much higher than what the writer anticipated finding. Table IV represents this higher than expected educational level of the parents. 
TABLE IV

EDUCATIONAL ACHIEVEMENT OF PARENTS

\begin{tabular}{llllll}
\hline & \multicolumn{2}{c}{ Mother } & & \multicolumn{2}{c}{ Father } \\
& $\%$ & $\mathrm{~N} n$ & & $\mathrm{~N}$ \\
\hline $\begin{array}{c}\text { Some High School or High } \\
\text { School graduate }\end{array}$ & 100 & 33 & & 100 & 21 \\
$\begin{array}{c}\text { Some Technical/ Vocational } \\
\text { training or graduate of same } \\
\begin{array}{c}\text { Some College or College } \\
\text { graduate with any degree }\end{array}\end{array}$ & 15 & 5 & 38 & 8 \\
\hline
\end{tabular}

By family (the highest level attained by one or both parents), 20 per cent $(N=7)$ had reached only the high school level. Another 20 per cent $(N=7)$ had completed some or graduated from vocational or technical training. But the most significant educational statistic was that 60 per cent $(N=21)$ of the families had at least one parent who had completed some college or had a college degree; 6 per cent $(\mathrm{N}=2)$ of the women and 10 per cent $(\mathrm{N}=2)$ of the men had received advanced college degrees. Of those families in which a parent had graduated from college at a bachelors level or with an advanced degree there was no opposition to the school teaching any of the family life topics. With 60 per cent of the sample having some college experience you could expect the occupations of the se parents to be more white collar than blue collar. The occupations of both parents were reported by 83 per cent $(N=29)$ of the sample. Of this, 69 per cent 
$(N=20)$ were either professional or business workers and the remaining 31 per cent $(N=29)$ were skilled and semi-skilled workers (see Appendix $D$ for a specific listing of these occupations). All but one of the blue collar workers was a skilled laborer. In 41 per cent $(N=12)$ of the sample reporting the occupations of both parents, each of the parents were employed outside of the home. The skewed distribution of occupations (more white collar and skilled laborers than semiskilled or unskilled laborers) and the extent of families in which both parents were employed indicates that the incomes of these families would be higher than one would expect for an average range of families.

Family life education has been objectionable to some parents because of their religious orientations. In the personal data section of the PAQ, the writer asked specifically with which church the parents were affiliated in an effort to ascertain any relationship between their church affiliation and their convictions and attitudes concerning family life education. The finding of Kerckhoff and The Family Coordinator Family Life Education Reaction Panel indicates that those parents whose church preference was more "fundamentalist" or "orthodox" would be against the teaching of aspects of a family life curricula (p. 105, 106). However, the largest percentage of parents opposed to any of the family life topics being taught in the schools came from the 29 per cent $(N=10)$ of the sample which did not 
answer the church affiliation questionor answered "none." Of this group, 60 per cent $(\mathrm{N}=6)$ felt that certain family life topics should not be taught by the school to their children. On the surface this does not appear to be consistent with the findings of Kerckhoff and panel as discussed above. But it should be stressed that since four parents of this sub-group opposing family life education topics did not answer the church affiliation question for whatever reason (i.e., too personal, forgot, or did not have a church affiliation), this statistic is not as meaningful as previously intimated. The parent groupings of those affiliated with Protestant churches and those with the Catholic church each had a few members opposed to the teaching of such topics to their children, but on the whole it would appear that the religious orientation of the parents in this study was not a factor in their opposition to family life education.

\section{DATA ANALYSIS}

Upon receipt of the PAQ's the writer coded the information supplied by the parents and the data was punched onto IBM cards. A card sorting process was then utilized to tally the frequency of responses to each item of the PAQ. Further card sorting allowed for the recording of related sets of responses. For example, for those parents who disagreed with the teaching of "about one's family" their responses to "human sexuality" and "preparing for one's own family" 
were checked by a cross-tabulation process. This was also applied to other sets of topics.

The parental responses to questions two and five on the PAQ were isolated as were their responses to questions one, three, and four. The former being the indices for assessing the knowledge variable. The information collected by the TS was then used to verify the validity of the parents' knowledge as measured by questions two and five of the PAQ. After this process was completed the suppositional relationship between the identified variables (as set forth in the hypothesis to be tested by this study) could be analyzed. A chisquare test was deemed by the writer as being appropriate for the verification of the postulated relationship between variables.

\section{RESULTS}

The parents of the sample, as described above,did not oppose, to a significant extent, the teaching of specific family life education topics in the school. Their support and opposition is illustrated in Table V.

Question one asked parents if they thought specific topics should be taught in the school. Strong parental support is indicated in all but three topics. Although a majority of the parents supported the teaching of these three topics, as could be expected for one of the topics, "human sexuality", the support was not as much in 
TABLE V

PARENTAL RESPONSES TO QUESTION ONE (PAQ)

\begin{tabular}{|c|c|c|c|c|c|c|c|c|c|}
\hline \multirow[b]{2}{*}{ a. } & \multirow{2}{*}{$\frac{\text { Topic }}{\text { Personal growth and development }}$} & \multicolumn{2}{|c|}{ Agree } & \multicolumn{2}{|c|}{ Uncertain } & \multicolumn{2}{|c|}{ Disagree } & \multirow[t]{2}{*}{$\operatorname{Didn}^{t} t$} & \multirow[t]{2}{*}{ Answer } \\
\hline & & $100 \%$ & $\mathrm{~N}=35$ & & & & & & \\
\hline b: & About one's family & $63 \%$ & $\mathrm{~N}=22$ & $23 \%$ & $\mathrm{~N}=8$ & $14 \%$ & $N=5$ & & \\
\hline c. & About society & $94 \%$ & $\mathrm{~N}=33$ & & & $3 \%$ & $\mathrm{~N}=1$ & $3 \%$ & $\mathrm{~N}=1$ \\
\hline d. & Caring for yourself and your body & $94 \%$ & $\mathrm{~N}=33$ & $3 \%$ & $\mathrm{~N}=1$ & $3 \%$ & $N=1$ & & \\
\hline & Getting along with others & $97 \%$ & $\mathrm{~N}=34$ & & - & $3 \%$ & $N=1$ & & \\
\hline f. & Animal reproduction & $80 \%$ & $\mathrm{~N}=28$ & $17 \%$ & $N=6$ & $3 \%$ & $N=1$ & & \\
\hline g. & Human anatomy & $100 \%$ & $\mathrm{~N}=35$ & & & & & & \\
\hline h. & Human sexuality & $60 \%$ & $N=21$ & $23 \%$ & $\mathrm{~N}=8$ & $17 \%$ & $\mathrm{~N}=6$ & & \\
\hline i. & Preparing for one's own family & $66 \%$ & $N=23$ & $23 \%$ & $\mathrm{~N}=8$ & $8 \%$ & $\mathrm{~N}=3$ & $3 \%$ & $\mathrm{~N}=1$ \\
\hline
\end{tabular}


evidence as for the other topics. The reasons given by the parents in question four for opposing the teaching of "human sexuality" included a belief that: 1) it was too personal of a subject to be taught by the school; and also 2) expressed concern for the training and beliefs of those teaching such a topic. The following quotes are from various parents opposed to the school teaching "human sexuality:" . . I feel that personal sex should be taught in the home. I have seen many well-meaning people on school staffs whose intentions are good but who don't really know how to handle a subject that I consider so personal.

Another parent stated:

I definitely do not agree with sex education in the elementary level unless the teachers have degrees in psychology and are experienced in teaching this subject. It is too easy to let personal opinions enter in, especially in the case of elderly, single women.

Although 67 per cent $(N=4)$ of the parents opposed to the teaching of "human sexuality" cited reasons related to the teacher's training and experience, this same concern was expressed by 17 per cent $(N=3)$ of the parents who did not disagree with the school teaching any of the nine topics. As a result, 20 per cent $(N=7)$ of the sample regardless of their support or opposition to the topics being taught in the school expressed a concern for the teacher's training, beliefs, and experience. A slightly different objection was voiced by the parent who stated, Above the 7 th grade sex could be taught in a more explicit manner provided there were some moral values included-- 
sex is not like blowing your nose--since the school system feels it cannot teach morals then leave sex alone except as it is mentioned in anatomy and care of the body.

Another parent expressed the following: "I personally want the privilege of explaining this exciting part of life to my children and am anticipating it."

Objection was voiced by 14 per cent of the parents to the teaching of "about one's family." The remarks of these parents in question four does not elucidate the reas on for their opposition as specifically as indicated by those parents objecting to the teaching of "/human sexuality." However, all five of the parents who disagreed with the school's teaching "about one's family" were in agreement with its teaching "human sexuality." Furthermore, "about one's family" was the only topic that these five parents objected to the school's teaching. One of these five stated that, ". . my child is not old enough to comprehend what is being taught." Another stated, ". . . at the grade school level, I feel that the most intimate facts should be left until a later age." The age of the former parents' child was seven and the latter had two children: on 12 years and 14 years old respectively. From the parents' remarks the writer would surmise that they too perceived it to be too personal and perhaps coming too early for their children.

An interesting finding, as illustrated in Table V, is that the topics "personal growth and development" and "human anatomy", 
were supported by 100 per cent of the sample; the topic "animal reproduction" was opposed by one parent, as was the topic "caring for yourself and your body"--yet, "human sexuality" was not supported by 40 per cent of the sample. It would seem from the above that the parents of this sample do not perceive "personal growth and development, " "human anatomy, " "animal reproduction, " and "caring for yourself and your body" to be a component of one's understanding of his own sexuality. Therefore, it follows that the topic 'human sexuality" is viewed by the parents of this sample as a subject matter entailing something different than an understanding of what it means to be a sexual being. Hence, the remarks of the parent disagreeing with the school's teaching "human sexuality" as expressed in the statement, ". . I do not agree that detail[ed] explanations or diagrams of $\operatorname{sex}[$ ual] intercourse and the like should be taught. . . "is supportive of the writer's above contention.

Perhaps the most significant finding of this study resulted from the tabulation of the parent's responses to the questions two and five of the PAQ. These questions measured the knowledge held by parents concerning what topics were being taught and how they were taught. The writer found that even before verifying these responses it was obvious that a substantial percentage of the parents were uncertain whether or not these topics were being taught to their children. 
Table VI depicts the "uncertain" responses of parents to question two of the PAQ.

TABLE VI

PERCEN TAGE OF "UNCER TAIN" RESPONSES

TO QUESTION TWO (PAQ)

\begin{tabular}{llc}
\hline \multicolumn{1}{c}{ Topic } & $\%$ & $\mathrm{~N}$ \\
\hline & $\mathrm{N}=35$ & \\
a. Personal growth and development & 40 & 14 \\
b. About one's family & 54 & 19 \\
c. About society & 43 & 15 \\
d. Caring for yourself and your body & 26 & 9 \\
e. Getting along with others & 29 & 10 \\
f. Animal reproduction & 51 & 18 \\
g. Human anatomy & 49 & 17 \\
h. Human sexuality & 54 & 19 \\
i. Preparing for one's own family & 57 & 20 \\
\hline
\end{tabular}

The amount of uncertainty as indicated in Table VI has special meaning when compared with the opposition to the teaching of specific topics as set forth in Table V. Table VII portrays this comparison. 
TABLE VII

PARENTS OPPOSED TO THE TEACHING OF CER TAIN

FAMILY LIFE EDUCA TION TOPICS WHO WERE

"UNCER TAIN" IF TOPIC WAS BEING TAUGHT

\begin{tabular}{lcc}
\hline \multicolumn{1}{c}{ Topic } & $\begin{array}{c}\text { \% of parents } \\
\text { opposed to topic } \\
\text { opposed to } \\
\text { topic that were } \\
\text { uncertain }\end{array}$ \\
\hline Human sexuality & 17 & 67 \\
About one's family & 14 & 80 \\
Preparing for one's own family & 8 & 100 \\
\hline
\end{tabular}

Although the presence of some uncertainty by the parents concerning whether or not a specific topic was being taught by the school was anticipated by the writer, it was not expected that a definite majority of those parents who were opposed to the teaching of a specific topic would also be uncertain if, in fact, it was being taught. The writer believed that if a parent took a definite stance on the teaching of a specific family life education topic, especially if that stance was in opposition, that it would be based upon information that was not correct. This was set forth in Hypothesis II. The amount of uncertainty as indicated in Table VII is believed to be an indication of the validity of Hypothesis II. However, it must be noted that this cannot be verified because of the type of data collected and is only conjecture. The parents' responses to question five which asked 
how these topics were being taught, i.e., once a month, in regular units, when needed, and so forth, also reflected much uncertainty. Thirty-seven per cent $(\mathrm{N}=13)$ of the parents responded "uncertain." Another 11 per cent $(N=4)$ did not answer the question. Consequently, approximately 50 per cent of the sample did not need verification of their answer to question five.

Question four provided parents with an opportunity to explain the attitudes measured in question one. It also gave the parents a chance to vent any feelings or beliefs not previously mentioned. More importantly, question four provided the writer with a mechanism for checking the consistency of answers to question one. Most parents elaborated on their feelings in question four. However, 17 per cent $(N=6)$ of the sample did not answer the question or make any comments in the space provided at the end of the questionnaire. All those parents answering question four reflected answers consistent with their answers to question one.

Several parents indicated needs or beliefs that were unrelated to the focus of this study. One parent advocated the school teaching speed reading. Another felt the school's discipline code was not consistent with the home's and felt the school was not backing them up. However, one parent expressed the need to know how to open up family communication channels, to discuss the family life topics as well as other matters with the children. Evaluation of all these 
remarks were helpful in the assessment of parental attitudes.

\section{LIMITATIONS OF THE STUDY}

The knowledge held by parents, concerning what was being taught, by the school was a variable to be assessed to enable the testing of both hypothesis. Accurate information concerning what was being taught was solicited from the teachers with the TS, and was to be used to verify the accuracy of parental knowledge as measured by the PAQ. However, a response from each of the teachers was not received. The writer assumed that all of the teachers would complete and return the TS and that it would not be necessary to code the TS's and thus monitor the teacher's responses. This was based on the belief that the teachers would be concerned about the parents' knowledge and attitudes concerning family life education and would, by virtue of their profession, be more responsive to inquiries such as sought by this study. This assumption was invalid and resulted in the return of only two-thirds of the TS's. The reasons for this might be that teachers were too busy, were not interested in the nature of this research, had received too many questionnaires in the past, or perhaps the topics were confusing or unclear. Because the TS's were not coded, there was no mechanism for knowing if any of the specialty teachers had responded, or, to verify the possibility that some teachers of the $3 \mathrm{rd}$ and $7 \mathrm{th}$ grades had completed more 
than one TS (see Table II). Consequently, the validation process of checking parental knowledge was not possible and was a limitation of this study.

An additional limitation of this study was that the age of the child was not sufficient in determining the elementary school grade of which he was a member. Furthermore, if the child's grade had been established, for those families in which there were more than one child, the parental responses to the teachings of family life education topics, would theoretically vary with the ages of the children. Unfortunately, the PAQ did not allow for differential responses. It was noted from the parents' responses to question four of the PAQ that the topics did not denote the same meaning for all parents. Likewise, it was unclear to a teacher what was meant by one of the topics ("human sexuality"). One parent clarified an answer depending on what was meant by the topic "about one's family." It would seem that the training and experience of the teachers on one hand and the lack of such training for the parents on the other hand could result in the topics having different meanings for each group. Since the implicit nature of the content of each family life education topic was not reflected in the topics utilized in the PAQ and the TS, this fact is perceived to be a limitation of this study. 


\section{INTERPRETATIONS}

The responses of this randomly selected parent sample, if representative of the parent population of Jason Lee Elementary School, are an indication that the family life education program of this school does not receive much opposition from the parents. The sample contained parents with more education and more professional occupations than is normally expected. These facts and the large amount of support given to the teaching of family life education by these parents are confusing when examining the corresponding lack of certainty, in either direction, about what specific topics are taught by the school. It may be that these parents are apathetic or passive in their concern for what is being taught in the family life curriculum of Jason Lee School. This statement is based upon the strength of the attitudinal support given by these parents to the teaching of family life education and the uncertainty which they felt regarding what was being taught in such a curriculum.

The opposition to family life education in the schools so prevalent in the late 1960's seems to be waning, if the results of this study have any applicability to the general public. The intensity of the opposition as indicated by Brown may not be as pressing of an issue for the seventies as she contended (1970, p. 598).

The results of this study point in the direction of reduced 
concern over sex education being taught in the schools. This may have been caused by the writer not using the words "sex education" in the PAQ. This contention was not substantiated by the present study, but it does indicate that, at least for this school, sex education may not be as controversial an issue as it has been for other schools in the past.

Although the hypothesized relationship between the variables could not be tested, as discussed above, the writer entertains the belief that some indication of this relationship exists and is demonstrated by the large percentage of parental uncertainty concerning the school's teaching of specific family life education topics. A possible reason for this uncertainty could be that since the furor over family life education is not as much in evidence if, in fact, it still exists, the parents may have accepted it as a part of reality. The cliche "out of sight, out of mind" may have real meaning in this instance. It is possible that the media has contributed to their uncertainty. The coverage given to the opposition of family life education in the mass media has made it a sensational journalistic item. The parents of this sample with their higher than expected education may be readers that have become confused about the facts and fiction of this controversy and this may have contributed to their uncertainty. There is an indication that the specific topics utilized in the PAQ lacked clarity as to what was meant. They may have been too 
broad for the parents to know what the writer was representing with the topics. Hence, this discussion is purely conjecture.

The personal information concerning the parent sample, as discussed above, offers a possible explanation of the data collected in this study. As reported, 60 per cent of the sample had completed varying levels of college. This may have contributed to the amount of support given the teaching of family life education in the schools. Data concerning the occupations of these parents revealed a high percentage of professionals and skilled laborers and a significant absence of any unskilled or unemployed workers. Given the occupations of these parents, it would appear that the parents of the sample were of a middle-class or upper-middle-class income bracket and may have been an influence on the amount of support offered for the teaching of these family life topics by the schools. The religious preference of the parents in this study and specifically, their church affiliation, indicates the absence of any radical or fundamentalist religious beliefs. This, too, would seem to be a factor in the lack of much opposition to the teaching of these topics. The writer believes these indices, education, occupation, and religion to be an explanation for the strong support given by the parents of the sample for the teaching of the family life education topics as listed on the PAQ. The writer also posits that Jason Lee Elementary School is atypical in its parent population as depicted by this sample and that 
other schools in the Portland School District would differ greatly in their parent population profile.

The implications of the above data will be discussed in the next chapter. 


\section{CHAPTER V}

\section{IMPLICA TIONS}

Perhaps the most significant finding of this study was the seeming paradox between the large amount of parental support for family life education in the schools and the relatively high frequency of uncertainty by the parents concerning what was actually being taught. At face value, this could indicate that there is fertile ground for involvement of the parents in a program that would aim at reducing uncertainty, increasing parental knowledge, and reinforcing the support measured by this study. The writer recognizes the multiple difficulties to be encountered in setting up a program that would bring together parents and school personnel and running a program that would enhance the school's teaching of the family life material by responding to the parents' need for clarity. However, an outgrowth of this endeavor might be the development of more acceptable methodologies for the teaching of these topics. Further analysis of the causes of this uncertainty might reveal that the almost sensational journalism treatment of the opposition to family life education in the schools by the mass media has desensitized and confused the parents to the point of not knowing what was being taught. Or, the impact of the media 
may have satiated the public and resulted in the is sue dying and the facts being forgotten. Clearly this is speculation, but the implication of this discussion is that further study is indicated to answer these causal questions.

A second finding deemed important by the writer was the concern of parents, both opposed, and in favor, of family life education, for the training and beliefs of the family life educators. Explanations for this phenomena might indicate that parents are caught up in viewing teachers in an old fashioned stereotype of the teacher as spinster. This was alluded to by a parent's remarks as discussed above. Further study on the teachers might yield interesting findings; such as most teachers are married and have children of their own. However, this parental ambivalence may reflect the sophistication of these parents (the parents of this sample possessing perhaps higher educational achievements). One can assume that better educated parents are more apt to be concerned with teacher preparation for their respective subject areas. The concern for teacher preparation in family life education is not new and Somerville identified it as an obstacle to be overcome before such programs can be expanded and enriched (1971, p. 27). A possible additional study might be an examination of the qualitative and quantitative preparation of family life teachers in Oregon. A focus on teacher preparation could lead to an exploration of how the teachers feel about teaching these kinds 
of topics. A study on teacher attitudes and preparation might bring forth new and different information. Such a study might shed light as to whether teacher attitudes are picked up unconsciously by students and parents relative to specific topic areas.

The results of this study and the personal data supplied by these parents raises the question as to whether or not the parents in Jason Lee School are atypical. This suggests a possible study of the parents in other schools to compare not only the results of this study, but also the parent profiles of other schools with the parents of Jason Lee School.

The findings of this study could be interpreted as varying degrees of a much larger issue than family life education in the schools. The parents' uncertainty and their concern for the training and beliefs of the teachers could be the direct result of a lack of confidence in the school's ability to educate children. This erosion of confidence may have grown out of the writings of several contemporary authors who are very critical of what they believe are the school's restrictive influences on the learning process. There is some evidence in the difficulty many school districts encountered in attempting to pass bond issues that the public may be dissatisfied with the schools. A case in point is the Portland School District, wherein the 1971-1972 school year ended one month early and all district employees were given a 10 per cent cut in pay as a result of 
a bond issue being turned down by the voters. However, the issue of family life education in the schools may be overshadowed by new and more pressing issues such as the tax burden or the war in Vietnam and further study is certainly appropriate to delineate their existence. Nonetheless, family life education continues to deserve the attention of parents and educators, as well as other professionals $\mathrm{such}$ as social workers, since this aspect of the curriculum is so intimately related to the family and the changing values in our society. 


\section{BIBLIOGR A PHY}

American Social Hygiene Association. Family Life Education Resource Guide Grades 1-12. New York, American Social Hygiene Association, 1958.

Avery, Curtis E. Meet the E. C. Brown Trust Foundation. Portland, Oregon, E. C. Brown Trust Foundation. n. d.

Avery, Curtis E. and Lester A. Kirkendall. The Oregon Developmental Center Project in Family Life Education. Portland, Oregon, E. C. Brown Trust, 1955.

Avery Curtis E. and Margie R. Lee. "Family Life Education: Its Philosophy and Purpose." The Family Life Coordinator, XIII, No. 2, 1964. 27-37.

Avrunin, William. "Jewish Social Services." Social Work Year Book 1960, Edited by Russell H. Kurtz. New York, National Association of Social Workers, 1960. 338-343.

Baker, Luther G., Jr. "The Rising Furor Over Sex Education." The Family Coordinator, XVIII, No. 3, 1969. 210-217.

Bayles, Ernest E. and Bruce L. Hood. Growth of American Educational Thought and Practice. New York, 1966.

Behlmer, Reuben D. Family Life Education Survey: A Report. Indianapolis, Indiana State Board of Health, 1961.

Boehm, Werner S. "The Nature of Social Work." Social Work, III, No. 2, 1958. 10-18.

Bowman, Henry A. "Collegiate Education and Marriage and Family Living." The Annals of the American Academy of Political and Social Sciences, CCLXXII, November 1950. 148-155.

Bremmer, Robert. From the Depths. New York, University Press, 1956.

Bremmer, Robert. "A Note on the Role of Social Workers in the Reform Movement. " Perspectives on Social Welfare, Edited by Paul $\mathrm{E}$. Weinberge $\mathrm{r}$. London, The Macmillan Company, Collier-Macmillan Limited, 1969. 87-89.. 
Brim, Orville G., Jr. Education for Child Rearing. New York, Russell Sage Foundation, 1959.

Brown, Janet S. "Improving Famuly Life: Action and Reaction." Journal of Marriage and the Family, XXXII,No. 4, 1970. 598609.

Brown, Muriel W. "Organizational Programs to Strengthen the Family." Handbook of Marriage and the Family. Edited by Harold T. Christensen. Chicago, Rand McNally and Company, 1964. 823-880.

Bruno, Frank J. Trends in Social Work 1874-1956. 2nd ed. New York, Columbia University Press, 1957.

Buchmueller, A. D. "Family Life Education." Social Work Year Book 1960. Edited by Russell H. Kurtz. New York, National Association of Social Workers, 1960. 245-250.

Burgess, Ernest W. and Harvey J. Locke. The Family From Institution to Companionship. New York, American Book Company, 1945.

Burgess, Ernest W., Harvey J. Locke and Mary Margaret Thomas. The Family From Traditional to Companionship. 4th ed. New York, Van Nostrand Reinhold Company, 1971.

Butts, R. Freeman. "Search for Freedom: The Story of American Education." Contemporary American Education. 2nd ed. Edited by Stan Dropkin, Harold Full and Ernest Schwarcz. New York, The Macmillan Company, 1970. 86-114.

Catoni, Lucile. "Family Life Education for Public School Teachers." Social Casework, L, No. 7, 1969. 407-410.

Chandler, Barbara A. "The White House Conference on Children A 1970 Happening." The Family Coordinator, XX, No. 3, 1971. 195-205.

Christensen, Glen A. "An Analysis of Selected Issues in Family Life Education." Unpublished Ph.d. dissertation,. Michigan State University, 1958. 
Christensen, Harold T. "Development of the Family Field of Study." Handbook of Marriage and the Family. Edited by Harold T. Christensen. Chicago, Rand McNally and Company, 1964. 3-32.

Cohen, Nathan Edward. Social Work in the American Tradition. New York, The Dryden Press, 1958.

Cooper, David. The Death of the Family. New York, Pantheon Books, 1970.

Costin, Lela P. "A Historical Review of School Social Work." Social Casework, XIIX, No. 10. 1969. 439-453.

Cremin, Lawrence A. "The Revolution in American Secondary Education 1893-1918." Contemporary American Education, 2nd ed. Edited by Stan Dropkin, Harold Full and Ernest Schwarcz. New York, The Macmillan Company, 1970. 141-168.

Dewey, John. Democracy and Education. New York, The Macmillan Company, 1916.

Edwards, John N., ed. The Family and Change. New York, Alfred A. Kropf, Inc., 1969.

Eliot, Martha M. "Six Decades of Action for Children." Children Today, I, No. 2, 1972. 2-6.

Ferguson, Elizabeth A., ed. Social Work. 2nd ed. Philadelphia, J. B. Lippincott, 1969.

Fink, Arthur, C. Wilson Anderson and Merrill B. Conover. The Field of Social Work. 5th ed. New York, Holt, Rinehart, and Winston, Inc., 1968.

Folsom, Joseph K. Youth, Family, and Education. Washington, D. C., American Council on Education, 1941 .

Force, Elizabeth S. Teaching Family Life Education. New York, Bureau of Publications, Teachers College, Columbia University, 1962 .

Force, Elizabeth S. "Family Life Education 1970: A Regional Survey." The Family Coordinator, XIX, No. 4, 1970. 295-300. 
Frank, Lawrence K. "Challenge of Family Life Education." Merrill-Palmer Quarterly of Behavior and Development, V, No. 2, 1959. 67-79.

Frank, Lawrence K. "The Beginnings of Child Development and Family Life Education in the Twentieth Century." MerrillPalmer Quarterly of Behavior and Development, VIII, No. 4, 1962. 207-227.

Frasier, Roberta C. "Beware the Elephants." Journal of Marriage and the Family, XXIX, No. 2, 1967. 380-382.

Gallagher, Raymond J. "Catholic Social Services." Social Work Year Book 1960. Edited by Russell H. Kurtz. New York, National Association of Social Workers, 1960. 136-141.

Good, H. G. A History of American Education. 2nd edition. New York, The Macmillan Company, 1962.

Goode, William J. The Family. Englewood Cliffs, New Jersey, Prentice-Ha11, Inc., 1964.

Goode, William J. "Industrialization and Family Structure." A Modern Introduction to the Family, Revised ed. Edited by Norman W. Bell and Ezra F. Vogel。 New York, The Free Press, 1968. 113-120.

Ha11, Calvin S. and Gardner Lindzey, eds. Theories of Personality. 2nd ed. New York, Wiley, 1970.

Hudson, John William. "A Content Analys is of Selected Family Life Education Textbooks Used at the Secondary Level." Unpublished Ph. D. dissertation, Ohio State University, 1956.

Hunt, Maurice O. "Child Welfare." Social Work Year Book 1960. Edited by Russell H. Kurtz. New York, National Association of Social Workers, 1960. 141-157.

Illich, Ivan. Deschooling Society. New York, Harper and Row, 1971.

Jewson, Ruth. "The National Council on Family Relations - Decade of the Sixties." Journal of Marriage and the Family. XXXII, No. 4, 1970. 610-615. 
Johnson, F. Ernest and William J. Villaume. "Protestant Social Services." Social Work Year Book 1960. Edited by Russell H. Kurtz. New York, National Association of Social Workers, 1960. 441-451.

Kami, Michael J. "Planning for Change with New Approaches." Social Casework, LI, No. 4, 1970. 209-215.

Kephart, William M. The Family, Society and the Individual. 2nd ed. Boston, Houghton Mifflin Company, 1966.

Kerckhoff, Richard K. "Family Life Education in America." Handbook of Marriage and the Family, Edited by Harold T. Christensen. Chicago, Rand McNally and Company, 1964. $881-911$.

Kerckhoff, Richard K. and The Family Coordinator Family Life Education Reaction Panel. "Community Experiences with the 1969 Attack on Sex Education." The Family Coordinator, XIX, No. 1, 1970. 104-110.

Kilander, H. Frederick. Sex Education in the Schools. New York, The Macmillan Company, 1970.

Kirkenda11, Lister A. and Roger W. Libby. "Trends in Sex Education." The Individual, Sex, and Society. Edited by Calfred'B. Broderick and Jessie Bernard. Baltimore, The Johns Hopkins Press, 1969. 5-21.

Klemer, Richard H. "Helping Families Through Marriage Counseling and Family Life Education." The Family Coordinator, XVIII, No. 3, 1969. 298-300.

Lee, Margie R. "How Do Experts Define.Family Life Education?" The Family Life Coordinator, XII, No. 3-4, 1963. 105-106.

Leslie, Gerald R. "The Field of Marriage Counseling." Handbook of Marriage and the Family. Edited by Harold T. Christensen, Chicago, Rand McNally and Company, 1964. 912-943.

Leslie, Gerald R. The Family in Social Context. New York, Oxford University Press, 1967. 
Linsky, Arnold S. and George A. Spendlove. "Note on an Unusually High Response Rate to a Mail Questionnaire. " Journal of

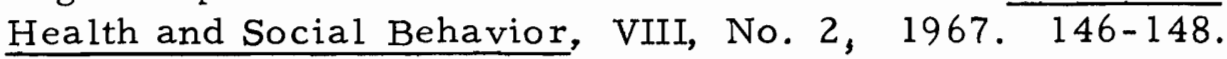

Lowe, Raymond N. "Parent-Teacher Education Through Family Counseling." The Family Life Coordinator, XI, No. 4, 1962. $87-90$.

Luckey, Eleanor B. "Education for Family Living in the Twentieth Century." Journal of Home Economics, LVII, No. 9, 1965. 685-690.

Luckey, Eleanor B. "Family Life Education and/or Sex Education." Journal of Marriage and the Family, XXIX, No. 2, 1967. 377-380.

Lurie, Harry L. "The Development of Social Welfare Programs in the United States." Social Work Year Book 1960. Edited by Russell H. Kurtz. New York, National Association of Social Workers, 1960. 19-49.

McHose, Elizabeth. Family Life Education in School and Community. New York, Teachers College, Columbia University, 1952.

McLuhan, Marshall. The Medium is the Massage. New York, Random House, Inc., 1967.

Manley, Helen. Family Life and Sex Education in the Elementary School. Washington, D. C., National Education Association of the United States, 1968.

Marshall, William H. "Family Life Education and or Sex Education." Journal of Marriage and the Family, XXIX, No. 2, 1967. $382-384$.

Murdock, George Peter. "The Universality of the Nuclear Family." A Modern Introduction to the Family, Revised ed. Edited by Norman W. Bell and Ezra F. Vogel. New York, The Free Press, 1968. 37-44.

Nass, Gilbert D. and Walter G. McIntire. "Improving Response Rates to Mail Questionnaires in Family Life Research." The Family Coordinator, XVII, No. 3, 1969. 240-243. 
Nixon, Richard M. "The State of the Union 1972." The Oregonian. January 21 , 1972, section 3, p. 37.

National Congress of Parents and Teachers. The Story of the Rocky Mounta in Project. Chicago, National Congress of Parents and Teachers, 1964.

National Council on Family Relations. "Position Paper on Family Life Education." The Family Coordinator, XIX, No. 2, 1970.186.

Otto, Herbert A., ed. The Family in Search of a Future. New York, Appleton-Century-Crofts, 1970.

Parsons, Talcott, Robert F. Bales and James Olds. Family Socialization and Interaction Process. Glencoe, Illinois, The Free Press, 1955.

Pederson, John Norman. "The Meaning and Implications of Family Life Education." Unpublished Ph. D. dissertation, Indiana University, 1951.

Power, Edward J. Main Currents in the History of Education. New York, McGraw-Hill Book Company, Inc., 1962.

Pulliam, John D. History of Education in America. Columbus, Ohio, Charles E. Merrill Publishing Company, 1968.

Report of the National Commission on Family Life Education, National Council on Family Relations. "Family Life Education: Principles, Plans, Procedures." The Family Coordinator, XVII, No. 3, 1968, 211-214.

Report of the Subcommittee on Preparental Education on Education for Home and Family Life, Part I, In Elementary and Secondary Schools to the White House Conference on Child Health and Protection. Anna B. Richardson, Chairman. New York, The Century Press Company, 1932.

Riegel, Robert E. American Women. Rutherford, Farleigh Dickenson University Press, 1970.

Robbins, Charles L. The School as a Social Institution. Boston, Allyn and Bacon, 1918. 
Running, Helen M. "In-Service Education for Teachers of Family Life Education From a Sociological Viewpoint." Unpublished Master's thesis. Portland State College, 1968.

Ryan, Michael Dennis. "An Evaluation of Opinions of Selected Students, Parents, and Professional Persons Concerning Curriculum Content for Instruction in Family Life and Sex Education at the Junior High School Level." Unpublished Master's thesis, University of Washington, 1969.

Schulz, Ester D. and Sally R. Williams. Family Life and Sex Education. New York, Harcourt, Brace, and World Inc., 1968.

Scott, Anne Firor., ed. The American Woman. Englewood Cliffs, New Jersey, Prentice-Hall, Inc., 1971.

Selltiz, Claire, Marie Jahoda, Morton Deutsch and Stuart W. Cook. Research Methods in Social Relations. Revised one-volume ed. New York, Holt, Rinehart and Winston, Inc., 1959.

Silberman, Charles E. Crisis in the Classroom. New York, Random House, Inc., 1970.

Smith, Patricia A. "Some Observations on Family Life Education at the Secondary Level." The Family Life Coordinator, VI, No. 4, 1958. 51-53.

Smith, William M., Jr. "Family Life Education - Who Needs It?" The Family Coordinator, XVII, No. 1, 1968. 55-61.

Somerville, Rose M. Family Insights Through the Short Story. New York, Teachers College, Columbia University, 1964.

Somerville, Rose M. "The Realtionship Between Family Life Education and Sex Education." Journal of Marriage and the Family, XXIX, No. 2, 1967. 374-377.

Somerville, Rose M. "Family Life and Sex Education in the Turbulent Sixties." Journal of Marriage and the Family, XXXIII, No. 1, 1971 . 11-35.

Stern, Edgar E. "Family Life Education: Some Rationales and Contents." The Family Coordinator, XVIII, No. 1, 1969. $39-43$. 
The Oregonian. Editorial, March, 14, 1972, section 1, p. 8.

Toffler, Alvin. Future Shock. New York, Random House, Inc., 1970 .

Weil, Rae C. "Family Social Work." Social Work Year Book 1960. Edited by Russell H. Kurtz. New York, National Association of Social Workers, 1960. 251-257.

Welch, Frank W. "Pooling Resources for Family Life Education." The Family Coordinator. XVII, No. 4, 1968. 293-296.

Wilensky, Charles and Harold Lebeaux. Industrial Society and

Social Welfare. New York, Russell Sage Foundation, 1958. 
APPENDIX A

Letter to Parents from Principal

Parental Assessment Questionnaire

Follow-up Letter from Writer

Personal Contact Procedure for Parents 


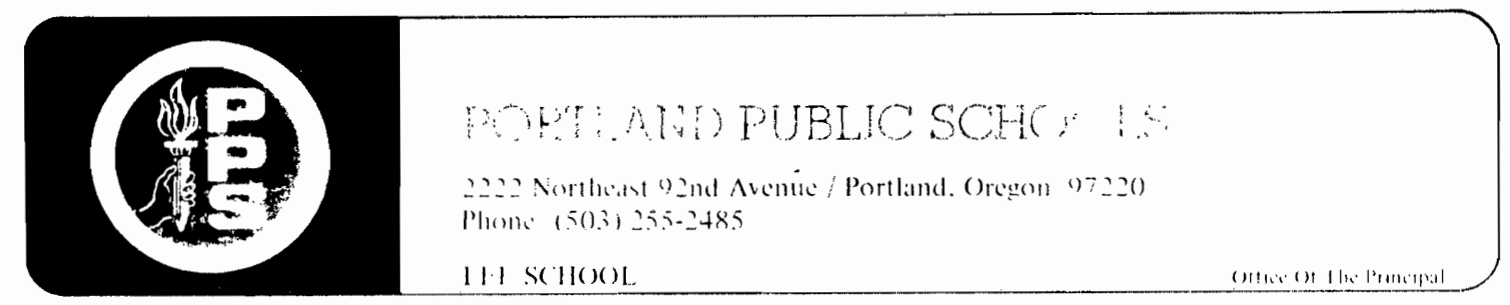

January 25, 1972

Dear Parents,

This letter will introduce you to Mr. Rick Siefke, a praduate student at Portland State University, who has received permission from the Area II staff of the Portland Public School $\varepsilon$ in sonduct some basic research in our area. Attached is the survey instrument of this educational research project.

Two copies of the instrument are included to allow both parents of the family to respond if their feelings or opinions differ. If you feel the same about the questions, one copy of the survey may serve for both.

Mr. Siefke is asking that the questionnaire be returned in the enclosed stamped self-addressed envelope by February 7 th.

Your name has been selected at random from the families at Jason Lee School, and, of course, your name will not be connected with the research in any way. Your cooperation with Mr. Siefke will be appreciated. I feel it 18 a worthwhile study and 1 ts results could benefit our school.

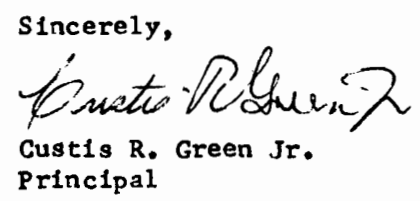


General instructions: These questions are being asked of a selected group of narents who have children attending Jason Lee Elementary School. There are no right or wrong answers. Please answer them as freely and as completely as you can.

Check list instructions: For each of the topics, a through $i$, check the answer to the questions 1,2 , \& 3 that best matches your answer.

TOPIC

\section{QUESTION}

Do you feel that the topic should

be taught to your child by the

school?

Yes, I

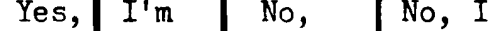

I uncer- I strongly agree

a Personal growth and development

$b$ About one's family

c About society

d Caring for yourself

and your body

e Getting along with others

$f$ Animal renroduction

$g$ Human anatomy

h Human sexuality

i Preparing for one's own family

4. Why do you feel that some or all of the above topics should or should not be taught by the schools?

QUESTION 2

QUESTION 3

Is the todic being If the school does teach this taught to your child tonic do you feel it has been by the school? helnful to your child?

Yes Uncertain No heloful ful ful tain ful

$+$

agree tain disagree disagree

\begin{tabular}{l|l|l} 
agree & tain & disagree \\
& & \\
& & \\
\hline
\end{tabular}

\begin{tabular}{l} 
\\
\hline \\
\hline
\end{tabular}

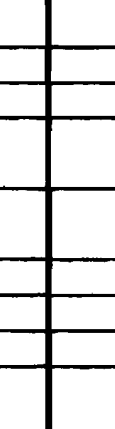

\begin{tabular}{|r}
\hline \\
\hline \\
\hline
\end{tabular}

Very Help-l hel heln- Uncer- Harm-

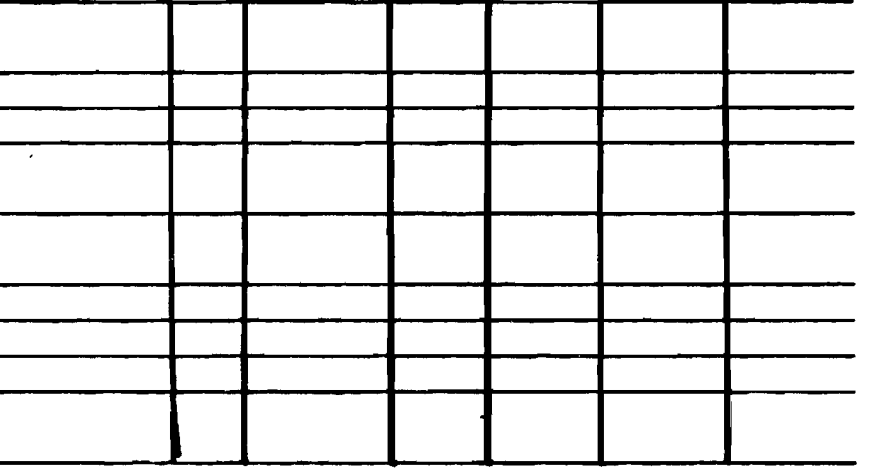


5. How are these topics being taught to your child by the school? (Circle the hest answer)

a. As a part of different units, as they apply; such as health, biology, social studies, etc.

b. On a regular basis; such as one day a week or one day a month

c. Once a year in one unit

d. As needed, when children's problems and interest arise

e. Uncertain

f. Other, specify

6. The space below is provided for any comments that you may have.

Your continued cooperation in this educational study involves a second set of questions, which are as imbortant as the first set. Although these questions are of a personal nature, do not sign your name so that confidentiality can be maintained.

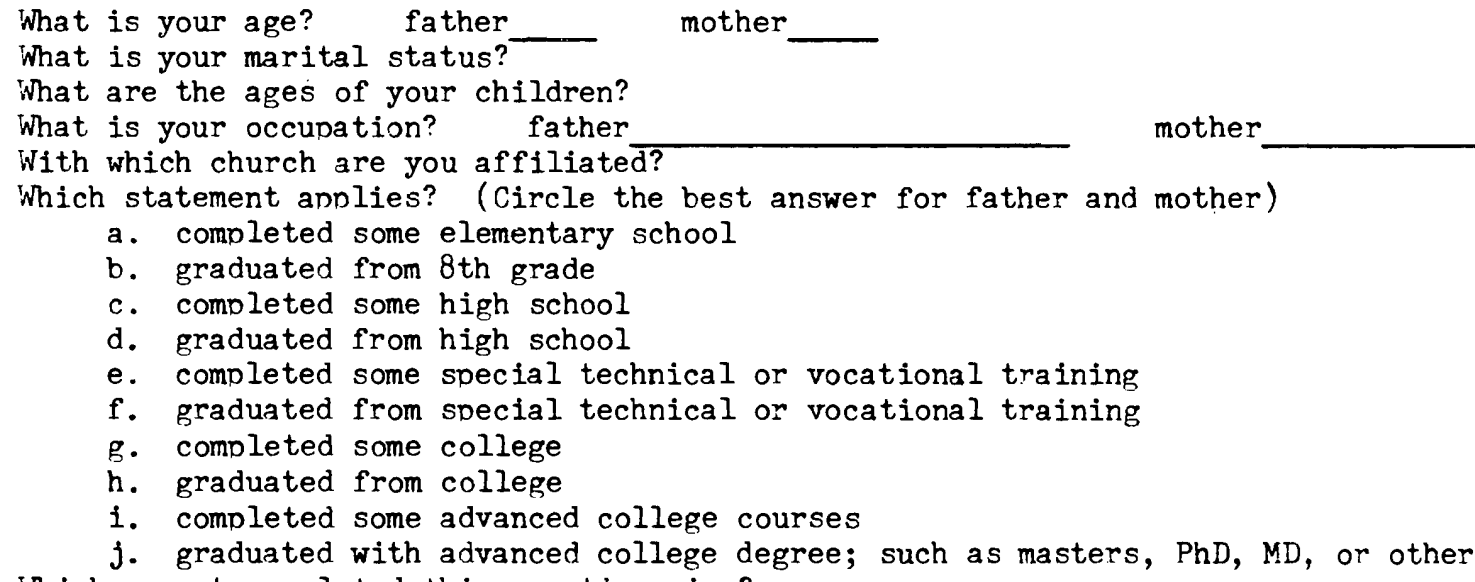

Thank you for your helo in this research. 
February 8, 1972

Dear Parents:

Recently, Mr. Curtis Green, the principal of Jason Lee Elementary School, sent you a letter which introduced me to you and explained that I am doing some research related to his school. As parents of a child attending Jason Lee you were randomly selected along with other parents from the families at the school to participate in this educational research.

The information received will be used in an analysis of parental feelings and knowledge concerning certain areas of the curriculum for elementary schools. I am happy to say that Mr. Green feels this study to be a worthwhile one and believes that the results could benefit his school.

Your answers to the questions will be kept confidential and your name will not be connected with this research in any way. It is important that the parents of every family selected complete their questionnaire. If you have not completed yours please take a few minutes and do so. Additional copies have been enclosed for your use if needed. Two copies are provided so that parents can express different views or opinions. Otherwise, one questionnaire will serve for both parents. A return envelope has been included for your convenience. To facilitate the analysis of the questionnaires it is necessary that they be returned by February 15, 1972.

The cooperation of every parent is needed to make this research meaningful to the school. Thank you for your participation.

Sincerely,

Rick Siefke

Graduate Student

Portland State University 
Personal Contact Procedure for Parents

'Hello, Mrs. (or Mr.) ?"

"My name is Richard Siefke and I'm conducting some research concerning Jason Lee School. I have sent out questionnaires to a group of parents whose children attend Jason Lee and you were among the group. "

"Several of the questionnaires have not yet been returned and I was wondering if you had returned yours? I have additional copies if you need them."

"I'11 be in this area again tomor row and I could stop by and pick up the questionnaire if that is convenient for you. "

"Thank-you." 


\section{APPENDIX B}

Letter to Teachers from Writer

Teacher Survey

Personal Contact Procedure for Teachers 
February 29, 1972

The Teachers of Jason Lee Elementary School

222 N. E. 92 nd

Portland, Oregon 97220

Dear Teachers:

I am conducting a survey of parents whose children attend Jason Lee School. This survey will be used to assess the amount of knowledge which these parents have concerning a portion of the school's curriculum and also to discover the parent's feelings regarding this area of their child's education.

To make use of the information obtained from the parents I need to know whether or not certain topics are, in fact, being taught to their children. As the teachers, you are in the best position to supply me with the knowledge of what is and isn't being taught. The attached form is being sent to you for that purpose.

So that I may have a full understanding of this aspect of the school's curriculum, it is necessary that each teacher participate. However, I do not need to know who teaches what, so do not sign the form. I am asking that you complete the form and return it to Mrs. Thomas by March 3, 1972.

Your cooperation will be appreciated. Thank you.

Sincerely,

Rick Siefke

Graduate Student

Portland State University 
Instructions: Check the grade or grades to which you teach the topics listed below. If you do not teach the topic please check the not applicable column, "N/A."

$\underline{\text { TOPIC }}$

GRADES

about society

personal growth

and development

caring for yourself and your body

getting along with others

human sexuality

about one's family

animal reproduction

preparing for one's own family

human anatomy

How do you teach the se topics to the children? (Circle the best answer.)

a. As a part of different units, as they apply; such as health, biology, social studies, etc.

b. On a regular basis; such as one day a week or one day a month.

c. Once a year in one unit.

d. As needed, when children's problems and interest arise.

e. Uncertain.

f. Other, specify

If you have any comments please use the back of this page for that purpose. 
$\underline{\text { Personal Contact Procedure for Teachers }}$

Introduction by Principal

"Thank you,"

"I've asked Mr. Green for the opportunity to speak with you today so that $I$ can discuss the research I am conducting and answer any questions that you might have concerning it. I realize that teacher meetings are not the most popular after school activity and since this is the second such meeting that you have had this week I will keep my remarks brief."

"You have all received a copy of my Teacher Survey questionnaire. The results of your responses to this instrument will be utilized as a baseline for the comparison of parental responses to similar questions in an attempt to test the correctness of their knowledge concerning what the school teaches their children in an aspect of its curriculum. Consequently, it is essential that I know what is being taught. At this point in time I have not received all of the Teacher Survey forms. Those of you present who have not completed yours yet, would you please do so by the end of the week and return them to Mrs. Thomas in the office. I need the cooperation of every teacher. "

"Do you have any questions?"

"I have brought additional copies of the Teacher Survey with me and I will leave them here for anyone who needs one."

"Thank you." 
APPENDIX C

Description of Jason Lee School 
Jason Lee Elementary School is a modest, one story facility that is well maintained and which provides a pleasant school environment. Located at 2222 N.E. 92nd, Portland, Oregon, the school is near the eastern boundary of the Portland School District. During the 1969-70 school year, the school had an average daily student population of 562 children. The class size is near the city average. The student population stability rate is in the top $10 \%$ of the district. The Jason Lee area had $3,4 \%$ of the $5-13$ age group children whose families received welfare. This is far below the city average. The black student population rate has been under $1 \%$. Scholastic achievement in computation, math concepts, problem solving, and reading for grades 3 and 5 are all in the top $30 \%$, However, grade 7 student achievement levels for the same areas are below the city average. This is contrary to the district trend which indicates that high achievement at grade 3 leads to relatively higher achievement in later years.

This information was taken from The Oregonian, March 14, 1972, Section 1, page 8 . 


\section{APPENDIX D}

Listing of Church Affiliation of Parents

Listing and Frequency of Highest Occupation

Represented per Family 
Listing of Church Affiliation of Parents

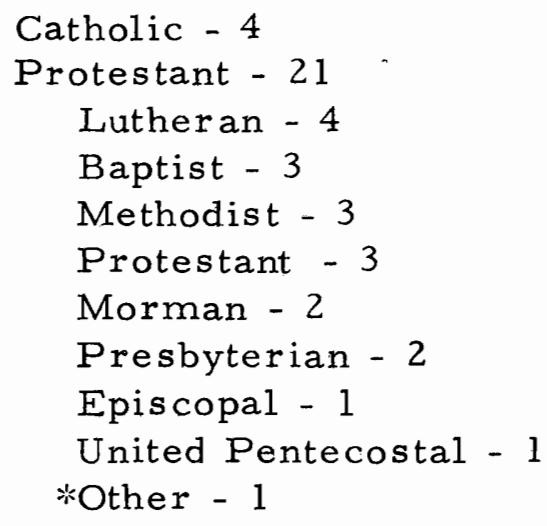

*Listed as such because handwriting was not legible. 
Listing and Frequency of Highest Occupation Represented per Family

Professional

Attorney - 2

Teacher - 2

Police officer - 2

Personnel worker - 1

Building Designer - 1

High School Counselor - 1

Personnel Administrator - 1

Business

Forman - 4

Salesman - 3

Contractor - 1

Appraiser - 1

Office Supervisor - 1

Skilled Laborer

Carpenter - 2

Radar Technician - 1

Electronics Technician - 1

Upholstery Refinisher - 1

Telephone Installer - 1

Longshoreman - 1

Steelworker - 1

Semi-Skilled Labor

Wa rehouseman - 1 


\section{APPENDIX E}

A Partial Listing of National Organizations on Record in Favor of Sex Education in the Schools 
A Partial Listing of National Organizations on Record in Favor of Sex Education Being Taught in the Public Schools*

American Association for Health, Physical Education and Recreation American College of Obstetricians and Gynecologists (Committee on Maternal Health)

American Publis Health Association (Governing Council)

National Congress of Parents and Teachers (PTA)

National Council of Churches

National Education Association and American Medical Association (Joint Committee on Health Problems in Education)

National School Boards Association and American Association of School Administrators (Joint Committee)

National Student Assembly, YMCA \& YWCA

Synagogue Council of America

United Nations Educational Scientific and Cultural Organization (UNESCO)

United States Catholic Conference

United States Department of Health, Education, and Welfare (U.S. Commissioner of Education)

*Taken from Luther G. Baker, Jr., "The Rising Furor Over Sex Education, "The Family Coordinator, XVIIL, No. 3 (1969), p. 216. 